\title{
Environmental Insights From High-Resolution (SIMS) Sulfur Isotope Analyses of Sulfides in Proterozoic Microbialites With Diverse Mat Textures
}

\section{Citation}

Gomes ML, DA Fike, KD Bergmann, C Jones, and AH Knoll. 2018. Environmental Insights From High-Resolution (SIMS) Sulfur Isotope Analyses of Sulfides in Proterozoic Microbialites With Diverse Mat Textures. Geobiology 16, no. 1 (January): 17-34.

\section{Permanent link}

http://nrs.harvard.edu/urn-3:HUL.InstRepos:41292726

\section{Terms of Use}

This article was downloaded from Harvard University's DASH repository, WARNING: This file should NOT have been available for downloading from Harvard University's DASH repository.

\section{Share Your Story}

The Harvard community has made this article openly available.

Please share how this access benefits you. Submit a story. 


\title{
Environmental insights from high-resolution (SIMS) sulfur isotope analyses of sulfides in Proterozoic microbialites with diverse mat textures
}

\author{
M. L. Gomes
1,2 D. A. Fike ${ }^{1}$ ～K. D. Bergmann ${ }^{3}$ | C. Jones ${ }^{1}$ | A. H. Knoll ${ }^{2}$
}

${ }^{1}$ Washington University, Saint Louis, MO, USA

${ }^{2}$ Harvard University, Cambridge, MA, USA

${ }^{3}$ Massachusettes Institute of Technology, Cambridge, MA, USA

Correspondence

M. L. Gomes, Johns Hopkins University, Baltimore, MD, USA.

Email:mgomes@jhu.edu

\begin{abstract}
In modern microbial mats, hydrogen sulfide shows pronounced sulfur isotope $\left(\delta^{34} S\right)$ variability over small spatial scales $(\sim 50 \%$ over $<4 \mathrm{~mm})$, providing information about microbial sulfur cycling within different ecological niches in the mat. In the geological record, the location of pyrite formation, overprinting from mat accretion, and postdepositional alteration also affect both fine-scale $\delta^{34} S$ patterns and bulk $\delta^{34} S_{\text {pyrite }}$ values. We report $\mu \mathrm{m}$-scale $\delta^{34} \mathrm{~S}$ patterns in Proterozoic samples with well-preserved microbial mat textures. We show a well-defined relationship between $\delta^{34} S$ values and sulfide mineral grain size and type. Small pyrite grains $(<25 \mu \mathrm{m})$ span a large range, tending toward high $\delta^{34} \mathrm{~S}$ values (-54.5\% to $11.7 \%$, mean: $-14.4 \%$ ). Larger pyrite grains $(>25 \mu \mathrm{m})$ have low but equally variable $\delta^{34} \mathrm{~S}$ values $(-61.0 \%$ o to $-10.5 \%$, mean: $-44.4 \%$ ). In one sample, larger sphalerite grains $(>35 \mu \mathrm{m})$ have intermediate and essentially invariant $\delta^{34} S$ values $(-22.6 \%$ to $-15.6 \%$, mean: $-19.4 \%$ ). We suggest that different sulfide mineral populations reflect separate stages of formation. In the first stage, small pyrite grains form near the mat surface along a redox boundary where high rates of sulfate reduction, partial closed-system sulfate consumption in microenvironments, and/or sulfide oxidation lead to high $\delta^{34} S$ values. In another stage, large sphalerite grains with low $\delta^{34} S$ values grow along the edges of pore spaces formed from desiccation of the mat. Large pyrite grains form deeper in the mat at slower sulfate reduction rates, leading to low $\delta^{34} \mathrm{~S}_{\text {sulfide }}$ values. We do not see evidence for significant ${ }^{34} \mathrm{~S}$-enrichment in bulk pore water sulfide at depth in the mat due to closed-system Rayleigh fractionation effects. On a local scale, Rayleigh fractionation influences the range of $\delta^{34} S$ values measured for individual pyrite grains. Fine-scale analyses of $\delta^{34} S_{\text {pyrite }}$ patterns can thus be used to extract environmental information from ancient microbial mats and aid in the interpretation of bulk $\delta^{34} S_{\text {pyrite }}$ records.
\end{abstract}

\section{1 | INTRODUCTION}

Microbial mats are multi-layered aggregations of phylogenetically and metabolically diverse microorganisms. Microbial mats can be preserved in the geological record as microbialites, which are ubiquitous through geological time (Grotzinger \& Knoll, 1999) and thus have the potential to provide a rich suite of information about the evolution of microbial metabolisms and ancient environmental conditions. Precambrian microbialites have received special attention because they provide insight into our understanding of early life on Earth. Additionally, it is likely that metabolic activity of microbial mat communities played a dominant role in biogeochemical cycling on the early Earth and thus influenced both nutrient and oxygen availability (Hoehler, Bebout, \& Des Marais, 2001; Anbar \& Knoll, 2002; Hayes \& Waldbauer, 2006). 
Methodological and technological advances in geochemical imaging and fine-scale analyses have made it possible to evaluate geochemical heterogeneity in both modern microbial mats and microbialites over small spatial scales (i.e., $\mu \mathrm{m}$-scale). By coupling these analyses with petrological information about mat textures, it is possible to evaluate potential signatures of biological process at play at the time of formation, ancient environmental conditions, evidence for post-depositional alteration, and the influence of fine-scale heterogeneity on traditional bulk-scale (i.e., $>1 \mathrm{~cm}^{3}$ ) geochemistry. Here, we use this approach to evaluate sulfur isotope heterogeneity in sulfide minerals within microbialites from two time intervals in the Proterozoic Eon in order to explore patterns of sulfur cycling during this critical interval of Earth history.

Biogeochemical sulfur transformations are an important component of elemental cycling in microbial mats (Canfield \& Des Marais, 1993; Habicht \& Canfield, 1996; Fike, Gammon, Ziebis, $\&$ Orphan, 2008; Fike et al., 2009). Many modern microbial mats contain an upper pigmented layer with oxygenic phototrophs (e.g., Cyanobacteria) overlying and admixed with anoxygenic phototrophs (e.g., certain taxa of the Chloroflexi and Proteobacteria such as the Chloroflexales and Chromatiales, respectively). These phototrophic communities fix carbon to produce energy and biomass, fueling mat growth and thereby providing a substrate for heterotrophic communities. Sulfide is generated in the mats via microbial sulfate reduction (MSR), a process by which microorganisms (e.g., certain orders of the Proteobacteria such as the Desulfobacterales) use sulfate to respire organic carbon $\left(\mathrm{CH}_{2} \mathrm{O}\right)$ or hydrogen $\left(\mathrm{H}_{2}\right.$, not shown in the reaction below), generating hydrogen sulfide $\left(\mathrm{H}_{2} \mathrm{~S}\right)$ and bicarbonate $\left(\mathrm{HCO}_{3}{ }^{-}\right)$:

$$
\mathrm{SO}_{4}^{2-}+2 \mathrm{CH}_{2} \mathrm{O} \rightarrow \mathrm{H}_{2} \mathrm{~S}+2 \mathrm{HCO}_{3-}
$$

The depth in the mat at which sulfide accumulates is called the sulfide chemocline. Diurnal cycles stimulate vertical migration of the sulfide chemocline (Canfield \& Des Marais, 1993; Fike et al., 2009). During the day, photosynthetic oxygen production and sulfide oxidation drive the sulfide chemocline to deeper within the mat. At night, the chemocline moves upwards as the result of continued sulfide oxidation in the absence of photosynthetic oxygen production (Canfield $\&$ Des Marais, 1993).

Sulfur isotopes provide a powerful tool for exploring patterns of sulfur cycling in microbial mats and other Earth surface environments. They are often quantified as the relative concentration of the two most abundant stable isotopes of sulfur, ${ }^{32} \mathrm{~S}$ (95.02\%) and ${ }^{34} \mathrm{~S}(4.22 \%)$, in delta notation $\left(\delta^{34} \mathrm{~S}\right)$ as a permil (\%o) deviation from the sulfur isotope composition of the Vienna Canyon Diablo Troilite (V-CDT) reference standard.

The primary process that fractionates sulfur isotopes in Earth surface environments is MSR. During MSR, microorganisms preferentially utilize ${ }^{32} \mathrm{~S}$, and therefore, the product, sulfide, can be depleted in ${ }^{34} \mathrm{~S}$ by up to $\sim 70 \%$ relative to sulfate (Canfield, Farquhar, \& Zerkle, 2010; Sim, Bosak, \& Ono, 2011; Wing \& Halevy, 2014). The magnitude of $\delta^{34} S$ fractionation during MSR $\left(\varepsilon_{\mathrm{SR}}\right)$ depends on cell-specific sulfate reduction rates (csSRR; Habicht \& Canfield, 1996; Sim, Bosak et al., 2011; Sim, Ono, Donovan, Templer, \& Bosak, 2011; Leavitt, Halevy, Bradley, \& Johnston, 2013) and ambient sulfate concentrations (Habicht, Gade, Thamdrup, Berg, \& Canfield, 2002; Wing \& Halevy, 2014; Bradley et al., 2015). First, there is a negative correlation between net sulfate reduction rate and $\varepsilon_{\mathrm{SR}}$ values that has been well documented in microbial cultures (Harrison \& Thode, 1958; Kaplan \& Rittenberg, 1964; Chambers, Trudinger, Smith, \& Burns, 1975) and marine sediments (Goldhaber \& Kaplan, 1975). Low csSRR, which contribute to a low net sulfate reduction rates in a system, can result from limitation by organic carbon availability, nutrient availability, low sulfate levels, high sulfide concentrations, or a combination of these factors (Wing \& Halevy, 2014; Bradley et al., 2015). Second, $\varepsilon_{S R}$ values tend to scale with ambient sulfate concentrations, which can reflect strain-specific relationships between sulfate concentration and fractionation (Habicht et al., 2002; Wing \& Halevy, 2014; Bradley et al., 2015) or Rayleigh isotope fractionation as the sulfate reservoir is more readily depleted when sulfate levels are low (Gomes \& Hurtgen, 2013). However, the relationship between sulfate concentration, csSRR, and $\varepsilon_{\mathrm{SR}}$ values differs among microbial species (Bradley et al., 2015) and may have varied over Earth history in association with secular changes in ocean chemistry and/or biological evolution.

Sulfide oxidation is also a globally significant process (Jorgensen, 1982; Canfield, 1991). However, the magnitude of $\delta^{34} S$ fractionations reported for various sulfide oxidation pathways is small ( $<10 \%$; Kaplan \& Rafter, 1958; Kaplan \& Rittenberg, 1964; Ivanov, Gogotova, Matrosov, \& Zyakun, 1977; Fry, Gest, \& Hayes, 1988; Zerkle, Farquhar, Johnston, Cox, \& Canfield, 2009; Poser et al., 2014) relative to $\varepsilon_{S R}$ values. Although sulfide oxidation can be important for driving overall $\delta^{34} S$ patterns, particularly in shallow marine sediments (Aller, Madrid, Chistoserdov, Aller, \& Heilbrun, 2010; Fike, Bradley, \& Rose, 2015), the consensus is that environmental controls on MSR play the dominant role in determining the evolution of $\delta^{34} \mathrm{~S}_{\text {sulfide }}$ values with depth in a sedimentary environment.

In the case of cyanobacterial mats from Guerrero Negro, Baja California Sur, Mexico, $\delta^{34} \mathrm{~S}_{\text {sulfide }}$ patterns with depth in the mat are interpreted in terms of changes in average csSRR because sulfide abundances were $<1 \%$ of ambient sulfate concentrations, and therefore, neither sulfate limitation nor Rayleigh isotope effects influence $\delta^{34} \mathrm{~S}_{\text {sulfide }}$ trends (Fike et al., 2009). In the top 1-4 mm of the mat, $\delta^{34} \mathrm{~S}_{\text {sulfide }}$ values are $\sim 15 \%$ - $40 \%$ o higher than $\delta^{34} \mathrm{~S}_{\text {sulfide }}$ values deeper in the mat (Fike et al., 2008, 2009). Additional $\delta^{34} \mathrm{~S}_{\text {sulfide }}$ oscillations ( 20\%) occur well below the chemocline $(\sim 1.5 \mathrm{~cm})$, and these are interpreted to reflect variable $\varepsilon_{\mathrm{SR}}$ at depth due to differential microbial metabolic activity that arises from different microbial populations, variations in availability of carbon substrates or other metabolites, or additional sulfur species (e.g., polysulfides) at depth. However, the consistent trend that emerges is that $\delta^{34} \mathrm{~S}_{\text {sulfide }}$ values are high near the surface redox boundary and decrease with distance from the redox boundary (Figure 1). Similarly, microbial consortia in marsh environments show a trend of high $\delta^{34} \mathrm{~S}_{\text {sulfide }}$ values near the redox boundary due to differential microbial metabolic activity rather than closed-system Rayleigh isotope effects (Wilbanks et al., 2014). Experimental evidence indicates that 
(a)

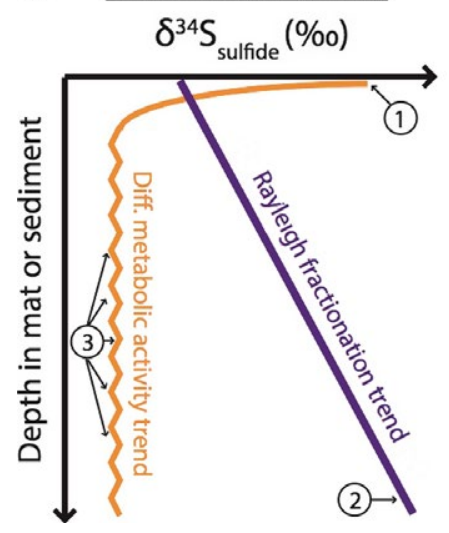

(b) Overlapping trend*

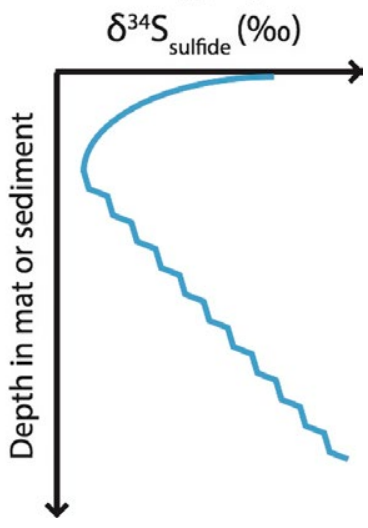

FIGURE 1 Schematic diagram depicting pore water $\delta^{34} S_{\text {sulfide }}$ patterns with depth in microbial mats or marine sediments. Left profile shows $\delta^{34} S_{\text {sulfide }}$ patterns driven by differential (diff.) metabolic activity in microbial mats (orange) and Rayleigh isotope fractionation trends in modern marine sediments (purple). The right profile shows a pore water $\delta^{34} \mathrm{~S}_{\text {sulfide }}$ profile (blue) where the differential metabolic trend is superimposed upon the Rayleigh isotope fractionation trend (i.e., the overlapping trend). *The overlapping trend is an idealized profile and, therefore, it should be noted that the depth and isotopic range varies greatly in natural systems because of differences in sedimentation rate, organic carbon and oxidant availability, and transport processes. See the Section 4 for explanations of points 1, 2, and 3

sulfate concentration also influences $\delta^{34} \mathrm{~S}_{\text {sulfide }}$ patterns; mat incubations at low sulfate concentration $(<1 \mathrm{~mm})$ show smaller $(\sim 5 \%){ }^{34} \mathrm{~S}$ enrichments in sulfide toward the top of the mat and $\delta^{34} \mathrm{~S}_{\text {sulfide }}$ values tend to be closer to $\delta^{34} S_{\text {sulfate }}$ values (Fike et al., 2009). Sulfide yields were low in these incubations, so it is unlikely that the $\delta^{34} \mathrm{~S}_{\text {sulfide }}$ trends are due to closed-system Rayleigh isotope effects. Rather, the $\delta^{34} \mathrm{~S}_{\text {sulfide }}$ patterns can be attributed to low $\varepsilon_{\mathrm{SR}}$ values associated with MSR at low sulfate concentrations, particularly when carried out by organisms that are otherwise adapted to higher sulfate concentrations (Bradley et al., 2015). Given how these trends vary with differential metabolic activity associated with microbial communities present at different depths in the mat and ambient sulfate concentration, $\delta^{34} S_{\text {sulfide }}$ patterns preserved in ancient mats can provide additional paleoenvironmental context to complement bulk $\delta^{34} \mathrm{~S}_{\text {pyrite }}$ records.

Pyrite $\left(\mathrm{FeS}_{2}\right)$ is an important geological archive of $\delta^{34} \mathrm{~S}_{\text {sulfide }}$ trends in sedimentary systems where it is a ubiquitous component of marine sediments. However, there is still uncertainty about pathways of pyrite formation in sedimentary environments (see Rickard, 2012 for a review). Although studies of modern systems have shown that $\delta^{34} S_{\text {pyrite }}$ values can be offset from pore water $\delta^{34} S_{\text {sulfide }}$ values by up to $40 \%$, the working hypothesis is that $\delta^{34} S_{\text {pyrite }}$ values reflect $\delta^{34} S_{\text {sulfide }}$ values at the location of pyrite formation (Lyons, 1997) and the offset is due to transport of pyrite grains, unsteady diagenetic regimes, or pyrite formation in microenvironments (Bruchert \& Pratt, 1996; Canfield, Raiswell, \& Bottrell, 1992; Chanton, Martens, \& Goldhaber, 1987; Raven, Sessions, Fischer, \& Adkins, 2016). Petrographic information can be used to assess these effects.

It should be noted that above $\delta^{34} S_{\text {sulfide }}$ trends with depth in microbial mats differ from pore water $\delta^{34} \mathrm{~S}_{\text {sulfide }}$ trends in some modern marine sediments (e.g., Hartmann \& Nielsen, 1968; Figure 1). Specifically, in some organic-rich modern marine sediments, pore water $\delta^{34} \mathrm{~S}_{\text {sulfide }}$ values are low near the top of the zone of sulfide accumulation and increase with depth. This pattern is a result of closed-system Rayleigh isotope fractionation effects where $\delta^{34} \mathrm{~S}_{\text {sulfide }}$ values evolve toward $\delta^{34} S$ values of the overlying sulfate reservoir as the sulfate reservoir is progressively consumed. Such isotopic profiles are common in systems with high organic carbon availability, low rates of diffusion, and/or low sulfate concentrations (Gomes $\&$ Hurtgen, 2015). It is possible that the trend of ${ }^{34} \mathrm{~S}$-enrichment due to high rates of sulfate reduction near the top of the zone of sulfate reduction could be superimposed upon the closed-system trend (e.g., Raven et al., 2016; Figure 1). The closed-system trend has not been documented in modern microbial mats because the fraction of sulfate consumed in the studied systems is too low (on the order of $1 \%)$ to produce measurable Rayleigh isotope fractionation effects (Fike et al., 2009). However, taking a holistic view that considers both modern microbial mat and marine environments, high $\delta^{34} S_{\text {pyrite }}$ values could reflect the capture of the $\mathrm{S}$-isotope signature of sulfide near the top of the zone of sulfate reduction (associated with high $\operatorname{csSRR}$, low $\varepsilon_{\mathrm{SR}}$ values, and oxidative sulfur cycling; Lyons, 1997; Habicht \& Canfield, 2001; Dale, Bruchert, Alperin, \& Regnier, 2009) or at greater depths where a large portion of the sulfate reservoir has been consumed. Another potential mechanism to generate high $\delta^{34} \mathrm{~S}_{\text {sulfide }}$ values, which could be captured in pyrite, is via Rayleigh isotope fractionation associated with MSR in microniches that are not well connected with the surrounding pore water. Intragrain $\delta^{34} S$ variability could add insight into the influence of this process on $\delta^{34} S_{\text {pyrite }}$ values. Petrography is a key tool that can be used to assess the environmental context of pyrite formation and to distinguish between these possibilities. Thus, by coupling petrographic observations with fine-scale geochemical analyses, it is possible to make inferences about the location of pyrite formation and extract additional paleoenvironmental information from fine-scale $\delta^{34} S_{\text {pyrite }}$ patterns.

To evaluate how fine-scale $\delta^{34} \mathrm{~S}_{\text {sulfide }}$ patterns in modern microbial mats are preserved in sulfides in microbialites, we present fine-scale $\delta^{34} S$ values of sulfide minerals from two microbialites from the Sukhaya Tunguska Formation, Siberia (MesoproterozoicNeoproterozoic transition; Sergeev, Knoll, \& Petrov, 1997) and one microbialite from the Draken Formation, Spitsbergen (Neoproterozoic; Knoll, Swett, \& Mark, 1991). We evaluate fine-scale $\delta^{34} S_{\text {pyrite }}$ patterns in the context of petrographic information and elemental mapping and compare the results to $\delta^{34} \mathrm{~S}_{\text {pyrite }}$ patterns from modern microbial mats (Fike et al., 2008, 2009) and microbial consortia (Wilbanks et al., 2014). This approach enables us to propose a framework for understanding the pyrite formation dynamics that influence bulk $\delta^{34} \mathrm{~S}_{\text {pyrite }}$ values in microbialites, an approach that can be extended to other types of sedimentary materials in order to gain additional insights into the spectrum of biogeochemical sulfur cycling associated with major Earth-life transitions in the past. 


\section{2 | MATERIALS AND METHODS}

\section{1 | Geological setting}

Our samples come from silicified microbialites preserved in two Proterozoic carbonate platforms. The Sukhaya Tunguska Formation is exposed in the Turukhansk Uplift, along the northwestern margin of the Siberian Platform. This 530- to 670-m-thick succession records a shallowing-upward sequence from subtidal, basinal limestones to peritidal dolomites (Petrov, 1993; Petrov, Semikhatov, \& Sergeev, 1995). Samples K95-101 and K95-103 come from a tidal flat/lagoonal unit midway through the formation (Petrov et al., 1995), which consists of intercalated dolarenite with low angle cross-stratification, dolomicrite, intraclastic conglomerate, and microbial laminite. Early diagenetic chert is common, particularly in the microbial mats, with excellent preservation of microfossils (Mendelson \& Schopf, 1982; Sergeev et al., 1997). Direct age constraints are limited, but on the basis of microfossils and stromatolites, Russian stratigraphers have generally recognized the boundary between the Sukhaya Tunguska and overlying Derevnya formations as the Middle-Upper Riphean boundary, implying an age slightly >1,000 Ma (Petrov et al., 1995; Semikhatov et al., 2000). Carbonate carbon isotope stratigraphy is consistent with this estimate (Bartley et al., 2001), as is a Pb-Pb carbonate date of $1,035 \pm 65 \mathrm{Ma}$ (Ovchinnikova et al., 1995).

The Draken Formation is exposed in the glaciated highlands of Spitsbergen. Part of the nearly two thousand meter thick carbonate Akademikerbreen succession (Knoll \& Swett, 1990), the 150- to 250-m-thick Draken Formation consists of tidal flat and lagoonal dolomites, including microbial laminites and low domal stromatolites, oolites, oncolites, and intraformational conglomerates, along with arenitic and micritic beds (Knoll et al., 1991; Fairchild, Knoll, \& Swett, 1991). Although Draken carbonates are almost entirely dolomitic, fabric retention is excellent, suggesting penecontemporaneous dolomitization (Fairchild et al., 1991). Desiccation cracks occur sporadically throughout the succession, and both tepees and fenestrae are common, underscoring the peritidal setting of most Draken carbonates. Early diagenetic silicification is also common, with excellent preservation of microfossils (Knoll et al., 1991). Sample P4705-A comes from the uppermost part of the formation, directly beneath the lowermost oolitic beds of the Backlundtoppen Formation; it consists of interlaminated grainstones and intraclasts of microbial laminite, with fabric specific silicification of the mat fragments. The age of the sample is constrained by the ca. 800 Ma Bitter Springs carbon isotope anomaly in the underlying Svanbergfjellet Formation (Halverson, Hoffman, Schrag, Maloof, \& Rice, 2005) and by the overlying 717-660 Ma Sturtian tillites (Rooney, Strauss, Brandon, \& Macdonald, 2015). Consistent with this age, Draken samples contain vase-shaped protistan microfossils comparable to those in successions from the Grand Canyon (Porter, Meisterfeld, \& Knoll, 2003) and northwestern Canada (Strauss, Rooney, Macdonald, Brandon, \& Knoll, 2014). The assemblage within the Draken is likely correlative with the older vase-shaped microfossils from both localities. If correct, the Draken Formation is older than $740 \mathrm{Ma}$ and well below the
Islay Anomaly, which is preserved in the overlying Russøya Member in Svalbard (Karlstrom et al., 2000; Hoffman et al., 2012; Strauss et al., 2014).

One reason for selecting samples from these two formations is that both sites have avoided significant post-depositional alteration. While both formations have been buried, involved in collisional tectonic events, and exhumed, the maximal temperatures experienced were similar, with no evidence for significant metasomatic fluid flow events. The Sukhaya Tunguska Formation of the Turukhansk Uplift experienced a collisional event following Mesoproterozoic deposition but prior to the Ediacaran (Nikishina, Sobornov, Prokopiev, \& Frolov, 2010). This faulting and uplift resulted in at least $3-4 \mathrm{~km}$ of erosion and maximum burial temperatures of $150-200^{\circ} \mathrm{C}$ (Frolov et al., 2015). The source rocks that have been studied from the Mesoproterozoic succession are post-mature but TOC-rich (Frolov et al., 2015). This is in contrast to the overlying Ediacaran stratigraphy whose source rocks are immature to early mature indicating the early burial and uplift of the Sukhaya Tunguska Formation was the only significant deformational event in its history (Frolov et al., 2015). The geochemical character of Sukhaya Tunguska carbonates (both dolomites and limestones) has low $\mathrm{Mn} / \mathrm{Sr}$ and $\mathrm{Fe} / \mathrm{Sr}$ ratios and display ${ }^{87} \mathrm{Sr} /{ }^{86} \mathrm{Sr}$ ratios, $\delta^{13} \mathrm{C}$ values, and $\delta^{18} \mathrm{O}$ values similar to other rocks of their age (Gorokhov et al., 1995; Pope, Bartley, Knoll, \& Petrov, 2003), which is consistent with minimal post-depositional alteration of the carbonates.

The Draken Formation is overlain by a significant overburden of Neoproterozoic to Ordovician rocks ( $\sim 3 \mathrm{~km}$; Knoll et al., 1991; Fairchild et al., 1991; Halverson, 2011). Additionally, deformation from the Caledonian Orogeny resulted in shortening and shear zones across Svalbard. However, this and more recent tectonic events appear to have had minimal thermal overprinting effects on the northern Ny Friesland succession (Fairchild et al., 2016). Thermal estimates of the Ordovician-aged strata indicate immature to early mature organic material from conodonts with CAI 1 (Lehnert, Stouge, \& Brandl, 2013). Fine-scale observations suggest early alteration of the samples during shallow burial (Knoll et al., 1991; Knoll, Fairchild, \& Swett, 1993; Fairchild et al., 1991). Geochemical analyses of carbonates from the Akademikerbreen Group are also similar to other carbonates of their age (Halverson, Wade, Hurtgen, \& Barovich, 2010; Fairchild et al., 2016). As both sites have avoided significant burial and tectonic overprinting, they allow us to explore trends in sulfur isotopes preservation from samples of different ages with minimal bias imposed by differences in the metamorphic and metasomatic history.

An additional motivation for selecting samples from these two sites is their similar peritidal depositional setting and early diagenetic history including fabric-retentive dolomitization and selective early silicification in both cases. The mat fabrics from each unit are almost always preferentially silicified, and both sites contain exceptional microfossil preservation of both filamentous forms and other types of mat dwellers (Mendelson \& Schopf, 1982; Sergeev et al., 1997; Knoll et al., 1991, 1993; Fairchild et al., 1991). Silicification preceded substantial decay of mat building and dwelling microorganisms. Insofar as pyrite formation preceded silica emplacement, this sharply constrains the timing of pyrite deposition. 


\section{2 | Bulk geochemical analyses}

Pyrite was extracted from homogenized samples using the chromium reduction technique (Canfield, Raiswell, Westrich, Reaves, \& Berner, 1986) in the Isotope Geobiology Laboratory at Harvard University. Briefly, powdered samples ( $1 \mathrm{~g}$ ) were loaded into vessels that were subsequently purged of $\mathrm{O}_{2}$ by $\mathrm{N}_{2}$ gas. Pyrite-S was extracted as $\mathrm{H}_{2} \mathrm{~S}$ by reaction with in boiling $1 \mathrm{~m}$ chromium chloride and $6 \mathrm{~N}$ hydrochloric acid for $2 \mathrm{hr}$ and driven by an $\mathrm{N}_{2}$ carrier gas to a trap vessel containing $0.3 \mathrm{~m}$ zinc acetate and $0.6 \%$ acetic acid and converted to zinc sulfide. An aliquot of the trap vessel was removed for concentration determination by the Cline method using a Thermo Scientific GENESYS 10S UV/Vis Spectrophotometer (Cline, 1969). The remaining ZnS was converted to $\mathrm{Ag}_{2} \mathrm{~S}$ and purified by rinsing with $1 \mathrm{M}$ ammonium hydroxide, which removes all silver salts besides $\mathrm{Ag}_{2} \mathrm{~S}$ (Firsching, 1961), and deionized water. For $\delta^{34} \mathrm{~S}$ measurements, $0.35-0.45 \mathrm{mg}$ of $\mathrm{Ag}_{2} \mathrm{~S}$ was weighed in tin boats along with $2-4 \mathrm{mg}$ of vanadium pentoxide. Measurements of $\delta^{34} S$ values were made on a Thermo Scientific Delta $\checkmark$ Plus continuous-flow isotope ratio mass spectrometer at Harvard University by combustion of $\mathrm{Ag}_{2} \mathrm{~S}$ to $\mathrm{SO}_{2}$. S-isotope measurements were reproducible within $0.2 \%$ o based on repeat analysis of international standards (IAEA S-1, IAEA S-2, and IAEA S-3).

Organic carbon concentration determinations were made on homogenized and acidified samples. To remove inorganic carbon, $\sim 1 \mathrm{~g}$ of powdered samples was treated with $3 \mathrm{~N}$ hydrochloric acid and allowed to react for $24 \mathrm{hr}$. The hydrochloric acid was removed by repeated rinses with deionized water. Calcium carbonate concentrations were determined gravimetrically based on loss during acidification. Organic carbon concentrations were determined on a Costech ECS 401 Elemental Analyzer coupled to a Delta V Plus mass spectrometer in the Stable Isotope Biogeochemistry Lab at Washington University. Analytical uncertainty is $\pm 0.1 \%$ o based on replicate analyses of laboratory standards.

\section{3 | Petrography}

Petrographic observations were made using a petrographic microscope. Images were taken using Leica EC4 Microscope camera. Scanning electron microscope images were also used for petrography (see Section 2.5).

\section{4 | Grain size determinations}

Grain diameters of sulfide minerals in thin sections were quantified from petrographic microscope images. These grain diameter values should be considered "apparent" grain size diameters because they were determined from the grain cross sections observed in thin section. If the thin section cut through the center of a spherical grain, then the measured diameter would represent the maximum diameter of the grain. In reality, the thin section exposes grain cross sections at random distances from the center of the grain. Therefore, the grain sizes reported here, and from similar studies of thin sections, are lower than the maximum diameter of the grain (assuming perfectly spherical grains). It is not standard procedure in many petrographic studies to perform a correction to account for this effect. However, we note that this effect should be considered when combining petrological observations with fine-scale geochemical analyses, particularly when trying to model environmental parameters giving rise to observed geochemical trends.

\section{5 | Elemental analysis}

Elemental mapping data and scanning electron microscope images were acquired using the JEOL-JXA-8200 Superprobe at the MIT Electron Microprobe Facility. Quantitative elemental spot analyses were carried out with an accelerating voltage of $15 \mathrm{kV}$, a beam current of $10 \mathrm{nA}$, and a beam size of $1 \mu \mathrm{m}$. Standards used for quantitative elemental analyses were chalcopyrite ( $\mathrm{S}$ and $\mathrm{Fe}$ ), hematite (O), and sphalerite $(\mathrm{Zn})$. Detection limits were as follows: $60 \mathrm{ppm}$ for $\mathrm{S}$, 130 ppm for Fe, 200 ppm for O, and 500 ppm for Zn. Error estimates based on measurements of the standards (expressed as standard deviation values) were as follows: 0.23 wt\% for S, 0.31 wt\% for Fe, 0.47 wt\% for $\mathrm{O}$, and 0.70 wt\% for $\mathrm{Zn}$.

\section{6 | Secondary ion mass spectrometry}

Secondary ion mass spectrometry (SIMS) measurements were made on the CAMECA IMS 7f-GEO at the Department of Earth and Planetary Sciences at Washington University on one-inch diameter round thin sections. Prior to mounting, a small ( 2 $\mathrm{mm}$ ) hole was made with a diamond dental drill in each sample and a piece of the Washington University in-house pyrite standard $\left(\delta^{34} S=0.13 \pm 0.30 \%\right.$; Meyer, Zerkle, \& Fike, 2017) was inserted with epoxy. This internal standard allowed us to correct for isotopic variability between sample holders and between different analytical sessions. Thin sections were mounted and prepared with double polishing by High-Mesa Petrographics. Samples were gold coated $(\sim 35 \mathrm{~nm})$ prior to analysis, in order to provide surface conductivity sufficient to sustain the stable secondary ion extraction field requisite for precise isotope ratio analysis. To further aid precision Cameca "Z-1" sample holders were used, these are specifically engineered to enhance the sample area available for precise isotope ratio analysis. Analyses were made in "spot mode." This term indicates data were acquired via bombardment with a $\mathrm{Cs}^{+}$ion beam rastered over a few micrometers, but without any specific $x, y$ registration of data origin other than the central coordinates of the beam in relation to the sample. (In contrast, scanning ion image mode would require a larger raster and data collection would be co-registered with the temporal beam coordinates.) There were 3-week-long sessions (May 2015, November 2015, and March 2016). The primary beam was set to a current of $\sim 1 \mathrm{nA}$ and a diameter of $\sim 2 \mu \mathrm{m}$ and was further rastered in a $2 \times 2 \mu \mathrm{m}$ grid to produce a $\delta^{34} \mathrm{~S}$ measurement for a $4 \times 4 \mu \mathrm{m}$ area. Note that an unrastered larger spot could have been employed, however, the smaller spot plus raster mode was chosen as it allowed more flexibility to engage in close-proximity transect and/or micro-grain analyses. Experiments comparing small 
spot plus raster mode with larger spot mode showed no difference in analytical precision.

Faraday cups were used to register relative ion currents for ${ }^{32} \mathrm{~S}$ (FC1; $>10^{8} \mathrm{c} / \mathrm{s}$ for 10 cycles) and ${ }^{34} \mathrm{~S}$ (FC2; $>4 \times 10^{6} \mathrm{c} / \mathrm{s}$ for 10 cycles) ions. Background levels on Faraday cups were calibrated at the beginning of each session and were $<2 \times 10^{4} \mathrm{c} / \mathrm{s}$ for ${ }^{32} \mathrm{~S}$ and $<4 \times 10^{3} \mathrm{c} / \mathrm{s}$ for ${ }^{34} \mathrm{~S}$. Automatic peak centering, mass calibration, and pre-sputtering (10 s over a $4 \mu \mathrm{m} \times 4 \mu \mathrm{m}$ area) were performed prior to each measurement. The small beam size $(\sim 2 \mu \mathrm{m})$ allowed for $\delta^{34} \mathrm{~S}$ measurements on small sulfide grains (i.e., $\sim 6 \mu \mathrm{m}$ ), with an average internal relative standard deviation (RSD) of $\sim 2.7 \%$ o (calculated for $n=10$ cycles for each sulfide analysis).

We performed a correction on sample and standard data to account for differences in the depth of ${ }^{32} \mathrm{~S}$ and ${ }^{34} \mathrm{~S}$ measurements. On the $7 \mathrm{f} / \mathrm{geo}{ }^{32} \mathrm{~S}$ and ${ }^{34} \mathrm{~S}$, data are acquired sequentially, repeated over a number of cycles. Counts of ${ }^{32} \mathrm{~S}$ and ${ }^{34} \mathrm{~S}$ are acquired for $0.96 \mathrm{~s}$ and $4 \mathrm{~s}$, respectively, with a 1.2-s wait time between analyses. This means that the time of acquisition for the ${ }^{32} \mathrm{~S}$ and ${ }^{34} \mathrm{~S}$ ions is slightly offset. This will not have an impact on measured $\delta^{34} S$ values if samples (and resulting ion counts) are homogenous; in our analyses, ${ }^{32} \mathrm{~S}$ and ${ }^{34} \mathrm{~S}$ counts each vary by $<10 \%$ over the course of 10 cycles in homogeneous standards. However, ${ }^{32} \mathrm{~S}$ and ${ }^{34} \mathrm{~S}$ counts in heterogeneous pyrite grains can vary by up to $45 \%$ over the course of 10 cycles of data collection. In these cases, the timing of collection for ${ }^{32} \mathrm{~S}$ versus ${ }^{34} \mathrm{~S}$ can bias $\delta^{34} \mathrm{~S}$ results. To correct for this bias, we perform a linear interpolation on ${ }^{32} \mathrm{~S}$ count data to calculate ${ }^{32} \mathrm{~S}$ count value that corresponds to the same time as the ${ }^{34} \mathrm{~S}$ measurement. This correction was performed on both standard and sample data.

The embedded standard was typically measured 2-4 times between every 9 and 15 sample measurements. We used the bracketing standard data to correct our sample data to minimize the effect of instrumental bias imposed by drift over the course of the analytical session (Valley \& Kita, 2009). Replicate analyses of the embedded Washington University in-house standard $\left(\delta^{34} S=0.13 \pm 0.30 \%\right.$; Meyer et al., 2017) and a separately mounted Balmat standard $\left(\delta^{34} \mathrm{~S}=15.1 \%\right.$ ) indicated that the average standard deviation (SD) of $\delta^{34} \mathrm{~S}$ values measured on isotopically homogenous samples is $0.3 \%$. However, due to the greater isotopic heterogeneity in our samples compared to the standards, we report $\delta^{34} S$ uncertainty for the unknowns as the $S D$ of individual sulfide grain data ( $n=10$ cycles). This $S D$ value is used to express the spread in the data over 10 cycles, but does not necessarily imply that the data were normally distributed because over 10 cycles the data were either randomly distributed around the mean or trended in a negative or positive direction. Data are provided in order of analysis in Table S1.

Sphalerite $(\mathrm{ZnS})$ grains were also analyzed by SIMS. Isotope ratios for sphalerite grains were calculated using a correction factor that was determined from the analysis of a Washington University in-house sphalerite standard with a known $\delta^{34} S$ value $\left(\delta^{34} S=3.5 \pm 0.3 \%\right.$ [ [2SD]; determined by gas-source isotope ratio mass spectrometry). The count rate for sphalerite grains was on average $1.5 \times$ the count rate of pyrite grains. Differences in the crystal orientation of sphalerite grains with respect to the incident primary $\mathrm{Cs}^{+}$beam have been shown to introduce an instrumental bias that can result in an inaccuracy of up to $3 \%$ if the standard grain has a different orientation from the sample (Kozdon et al., 2010); in contrast, pyrites have a maximum known orientation effect of $0.2 \%$ (Kozdon et al., 2010). We did not determine the extent of inaccuracy imposed by the crystal orientation effect in our analyses and therefore use the maximum value reported by Kozdon et al. (2010) as our uncertainty in Table S2.

To account for potential spatial $\delta^{34} \mathrm{~S}$ variability in larger pyrite grains (i.e., $>14 \mu \mathrm{m}$ ), we performed $\delta^{34} \mathrm{~S}$ measurements in grain transects along the central vertical and horizontal plane, as positioned in the SIMS and pictured in petrographic images. To evaluate biases imposed by closely spaced $(\sim 5 \mu \mathrm{m})$ measurements, we used the same method to measure vertical and horizontal transects on the Balmat standard. The close spacing (i.e., $5 \mu \mathrm{m}$ ) of measurements along the horizontal plane resulted in $\delta^{34} \mathrm{~S}$ variability of up to $5.4 \%$ on standards. This increased isotopic variability is attributed to differential ionization effects introduced by interactions between the incident primary $\mathrm{Cs}^{+}$ beam and adjacent pits made by previous measurements; this effect occurs because the incident primary $\mathrm{Cs}^{+}$beam approaches the surface of the sample at angle along the horizontal plane. Additional experiments determined that, for these analytical parameters, data were no longer compromised when a horizontal spacing $>8 \mu \mathrm{m}$ was used. This effect could also be avoided using diagonal steps for closely spaced measurements in orthogonal transects. The maximum $\delta^{34} \mathrm{~S}$ variability was much lower (i.e., 1.7\%o) on transects along the vertical plane (i.e., orthogonal to the angled direction of incident $\mathrm{Cs}^{+}$beam), where the impact of adjacent spots was minimal. Thus, here we only report $\delta^{34} \mathrm{~S}$ data for transects along the vertical plane. The $\delta^{34} S$ measurements from each grain transect were averaged to calculate $\delta^{34} S$ values for each pyrite grain, and we compare these values directly to the single $\delta^{34} \mathrm{~S}$ measurements made on individual grains.

\section{3 | RESULTS}

The studied thin sections include centimeter-scale microbial mats, mat clasts, and clastic layers, which contain smaller mat fragments (Figure 2). Petrographic observations using both transmitted and reflected light, supplemented with elemental analysis data, indicate that portions of the samples that appear dark in Figure 2 contain finely disseminated, small $(<25 \mu \mathrm{m})$ pyrite grains. The small pyrite grains represent $\sim 1 \%-2 \%$ of these dark mat textures. The mat textures appear to be dark in both cross-polarized and plane-polarized light and are interpreted to be organic-rich (Figures 2, 4, and 5). In the lighter portion of the samples (Figure 2), localized populations of larger (>25 $\mu \mathrm{m})$ sulfide grains were found on the edges of silicified void spaces. Thus, the general pattern is that small pyrite grains $(<25 \mu \mathrm{m}$ diameter) tend to occur in dark, organic-rich portions of the samples, while larger sulfide grains are found in organic-poor, silicified regions that appear transparent in plane-polarized light (Figures 2, 4, and 5). In what follows, we will describe each sample individually.

Petrography, elemental maps, and elemental analysis data from Sukhaya Tunguska Formation sample K95-101 indicate that the 


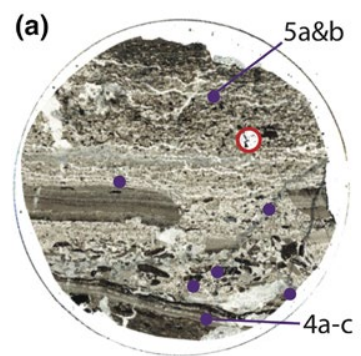

(b)

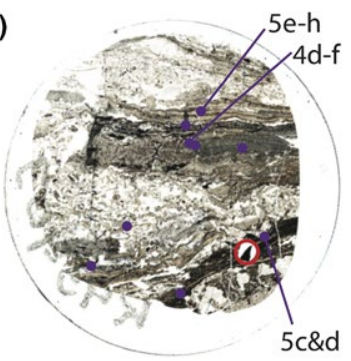

(c)

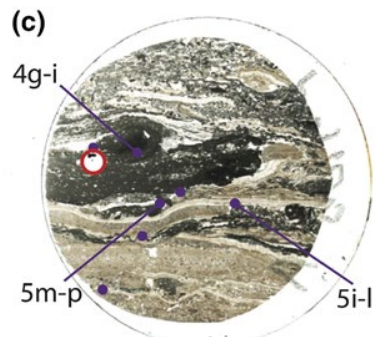

FIGURE 2 Microbialite thin sections: (a) K95-101 and (b) K95-103, both from the ca. 1,000 Ma Sukhaya Tunguska Formation, Siberia, and (c) P4705-A, from the ca. 750 Ma Draken Formation, Spitsbergen. Locations where sulfide minerals were analyzed by SIMS are indicated with purple filled circles (see Table S1 for $x$ and $y$ coordinates). The list below each thin section image indicates the sulfide grain \# that correspond to those listed in Tables S1 and S2 and figures with high-resolution images of the sulfide grains that correspond to each location. The location of the Washington University in-house standard is circled in red. Each thin section is $2.54 \mathrm{~cm}$ in diameter

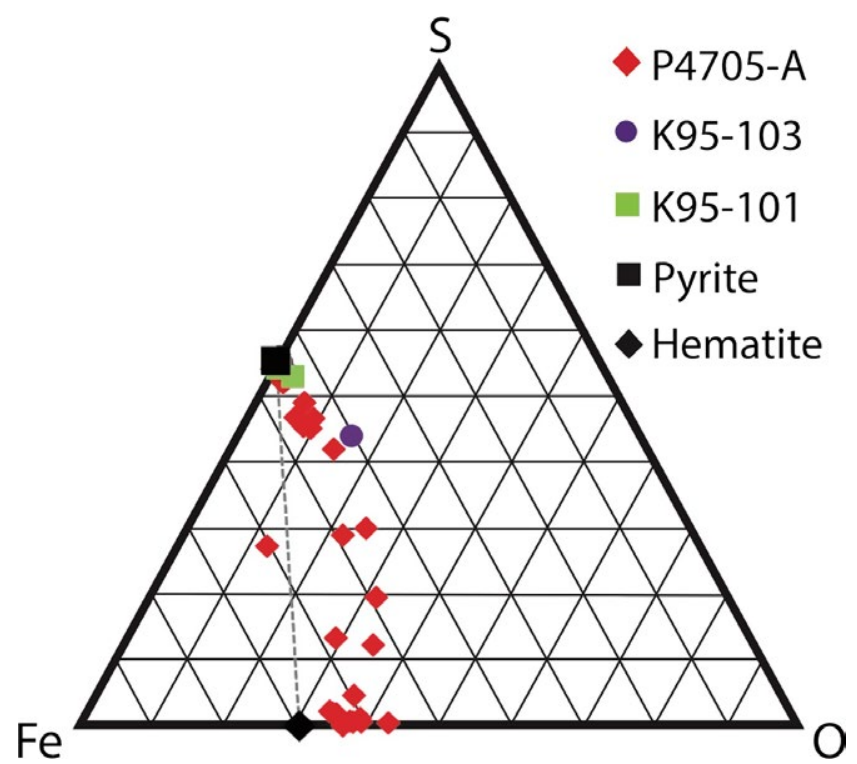

FIGURE 3 Ternary diagram of Fe, S, and O concentrations (wt\%) in P4705-A (red diamonds), K95-101 (green squares), K95-103 (purple circles), pyrite (black square), and hematite (black diamond). The gray dotted line indicates the mixing line between pure pyrite and pure hematite. P4705-A shows evidence of diagenetic pyrite oxidation. Only pyrites with low oxygen concentrations (generally $<1 \mathrm{wt} \%$ O) were analyzed for $\delta^{34} \mathrm{~S}$ values

sulfide grains in this sample are pyrite (Figures 3, 4a-c and 5a,b; Table S2). Most pyrite grains in this sample are small $(<25 \mu \mathrm{m}$; only one of the 18 samples analyzed by SIMS was $>25 \mu \mathrm{m}$ ), spherical, range from subeuhedral to euhedral grain textures, and cover $<1 \%$ of the area of organic-rich mat textures (Figures $4 a-c$ and $5 a, b$ ). Both the light and dark portions of the sample are silicified, with dolomite grains $(<50 \mu \mathrm{m})$ covering at most $\sim 10 \%$ of the organic-rich area (Figure $4 c$ ).

Sulfide grains in K95-103, also from the Sukhaya Tunguska Formation, are predominantly pyrite (Figures $3,4 d-f$ and $5 c, d, g$; Table S2), but also include some large (>35 $\mu \mathrm{m}$ diameter) sphalerite (ZnS) grains (Figure 5e-h; Table S2). Both the dark, organic-rich and lighter potions of the samples are silicified. Dolomite grains $(<50 \mu \mathrm{m})$ comprise $\sim 2 \%$ of the area in organic-rich mat textures of K95-103 (Figure $4 \mathrm{f})$. Small pyrite $(<25 \mu \mathrm{m})$ comprise $\sim 1 \%$ of the area of organicrich mat textures and have subeuhedral to euhedral spherical shapes (Figures $4 d-f$ and $5 c, d, g$ ). Large sulfide grains in K95-103 occur on the edges of silicified fenestrae and are predominantly sphalerite (Figure 5e-h; Table S2). The shapes of the sphalerite grains are highly irregular and may result from the aggregation of smaller particles (Figures 5e-h).

In the Draken Formation sample P4705-A, the concentrations of $\mathrm{S}$ and $\mathrm{Fe}$ in sulfide grains range from the weight percent predicted from the stoichiometry of pyrite $\left(\mathrm{FeS}_{2}: \mathrm{S} \approx 53.5 \mathrm{wt} \%, \mathrm{Fe} \approx 46.5 \mathrm{wt} \%\right)$ to more oxidized forms resembling iron oxides with $\mathrm{Fe} \approx 60 \mathrm{wt} \%$ and $\mathrm{O} \approx 30-35 \mathrm{wt} \%$ (Figures 3 and 5; Table S2). Only pyrites with low oxygen signal (generally $<1 \mathrm{wt} \% \mathrm{O}$ ) were analyzed for $\delta^{34} \mathrm{~S}$ data. Similar to the Sukhaya Tunguska Formation samples, small pyrite grains $(<25 \mu \mathrm{m})$ tend to occur in organic-rich mat textures (Figures $4 g-i$ and $5 m, n$ ). Small $(<25 \mu \mathrm{m})$ pyrite grains are subhedral to anhedral and comprise $3 \%-10 \%$ of the area of organic-rich mat textures, with higher percentages found in darker portions of the sample (Figures $4 \mathrm{~g}-\mathrm{i}$ and $5 \mathrm{~m}, \mathrm{n}$ ). In contrast to the Sukhaya Tunguska Formation samples, these organicrich sections are heavily dolomitized in sample P4705-A, with silica only representing $\sim 5 \%$ of the area (Figures $4 i$ and $50, p$ ). Large pyrite grains $(>25 \mu \mathrm{m}$ ) occur along the boundary of silicified vugs or channels (Figure $5 m-p)$. These grains can be euhedral and primarily pyrite (e.g., Figure 5o) or framboidal grains that show evidence for both overgrowths and differential oxidation of both framboid boundaries and interiors (e.g., Figure 5p). Large pyrite grains were also found in a silica-rich portion of a mat fragment (Figure $5 \mathrm{i}, \mathrm{j}$ ). These grains have morphologies consistent with formation by aggregation of smaller particles and have either anhedral (e.g., Figure 5I) or overgrown, subhedral framboidal shapes (e.g., Figure 5k).

In all three samples, mean $\delta^{34} \mathrm{~S}$ values of individual sulfide grains range around the sample bulk $\delta^{34} S$ values (Figure 6), which were determined from sulfide extracted via the chromium reduction method (Canfield et al., 1986). While generally assumed to reflect pyrite, the chromium reduction method recovers sulfide that is operationally defined as the chromium reducible sulfide (CRS) pool because it recovers sulfide from both pyrite and sphalerite (as well as other metal sulfide 


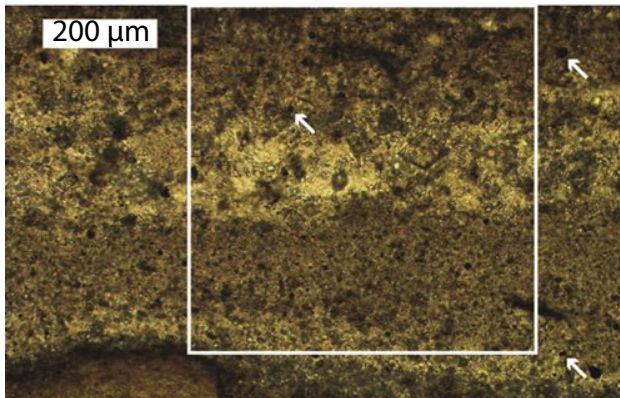

(a)
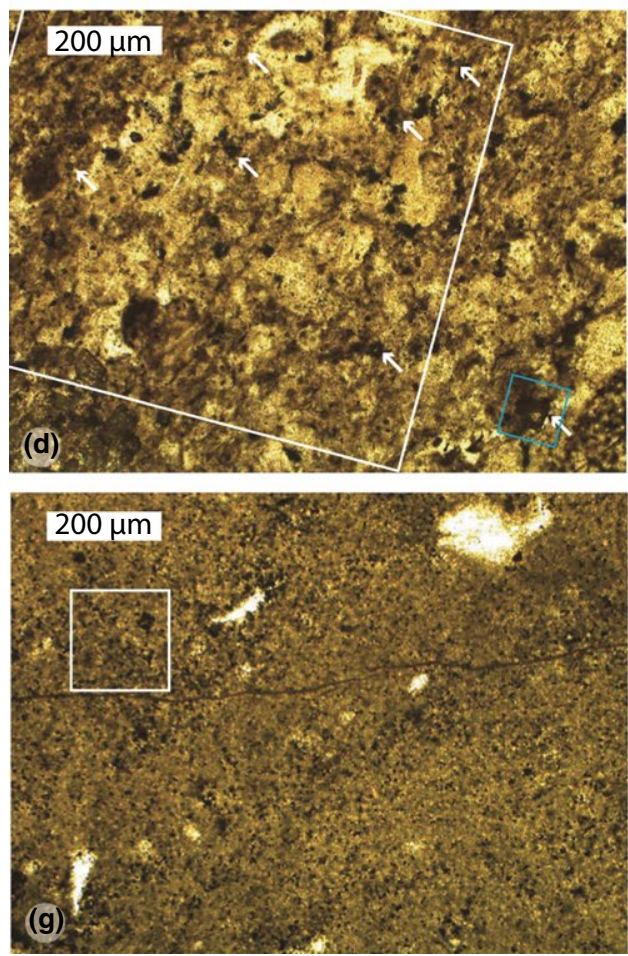
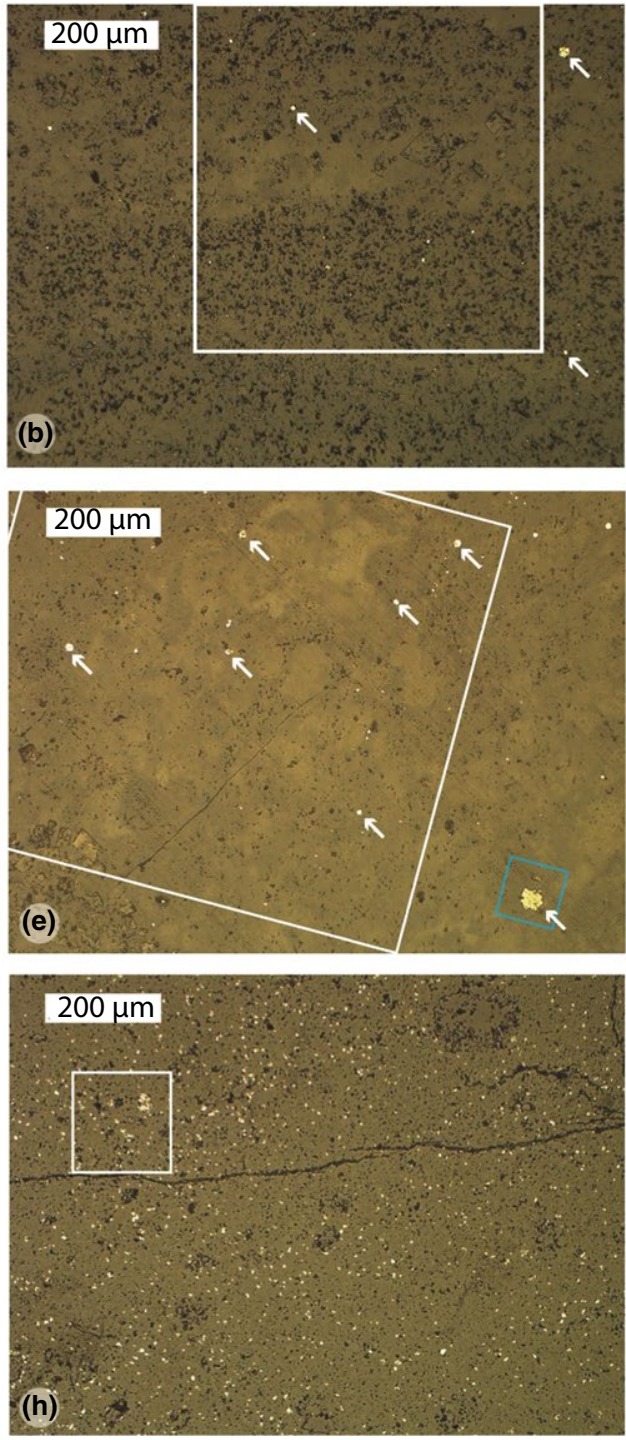
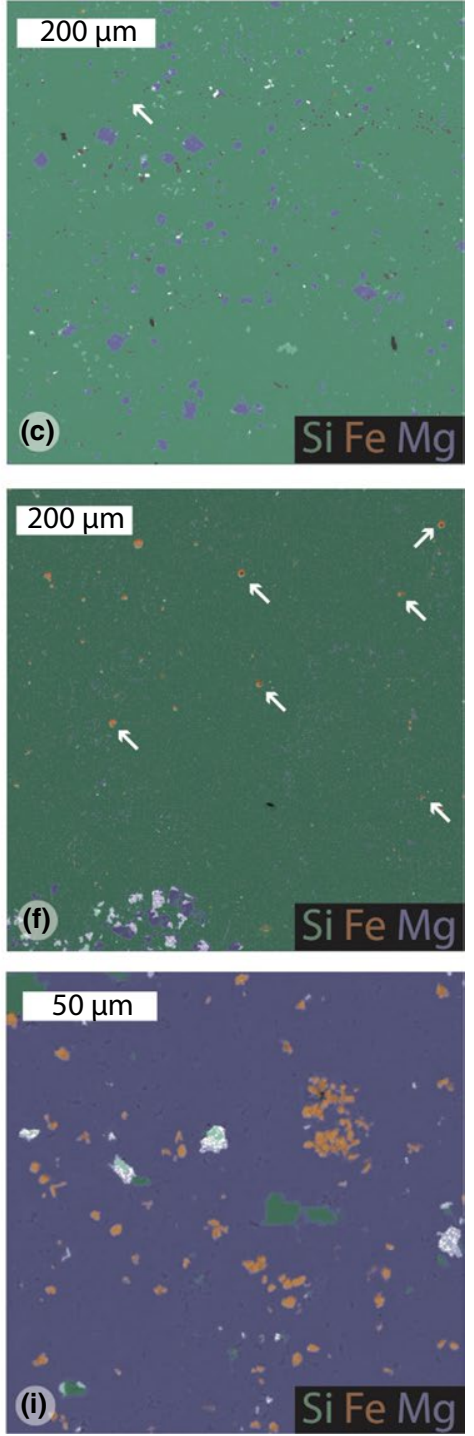

FIGURE 4 Images of organic-rich matrix with small pyrite grains $(<25 \mu \mathrm{m})$ : (a-c) K95-101 (d-f) K95-103, and (g-i) P4705-A. Images in the left-most column (a, d, g) are in plane-polarized light. Images in the center column (b, e, h) are in reflected light. Images in the rightmost column (c, f, i) are SEM images overlain by elemental maps, which show distributions of silica (Si, green), pyrite (indicated by Fe, orange), and dolomite (indicated by Mg, purple). The location of (c), (f), and (i) is indicated by white boxes in ( $\mathrm{a}$ and b), ( $\mathrm{d}$ and e), and (g and h), respectively. The blue box in (d) and (e) indicates the location of the image in Figure 5k. Pyrites appear in bright gold color in the reflected light images (b, e, h). White arrows (a-f) indicate pyrite grains that have been analyzed by SIMS. Pyrite grains in images (g), (h), and (i) were not analyzed by SIMS, but are shown here to provide an example of the microtextures associated with small pyrite grains in P4705-A

minerals) if no acid pre-treatment step is included. Individual pyrite grain $\delta^{34} \mathrm{~S}$ values in Sukhaya Tunguska Formation sample K95-101 range from $-11.6 \pm 3.1 \%$ o to $11.7 \pm 3.2 \%$, with a mean SIMS $\delta^{34} \mathrm{~S}$ value within the sample of $-4.5 \%$ ( $\sigma=5.7 \%, n=18)$. The bulk $\delta^{34} \mathrm{~S}_{\mathrm{CRS}}$ value for $\mathrm{K} 95-101$ is $0.6 \pm 0.2 \%$. The other sample from the Sukhaya Tunguska Formation, $\mathrm{K} 95-103$, has a slightly lower bulk $\delta^{34} \mathrm{~S}_{\mathrm{CRS}}$ value of $-5.1 \pm 0.2 \%$. Correspondingly, the mean individual grain $\delta^{34} S$ value for all sulfide grains in $\mathrm{K} 95-103$ is slightly lower at $-8.6 \%$ ( $\sigma=6.7 \%$, $n=24)$, with a range of $\delta^{34} S$ values between $-22.6 \pm 1.5 \%$ and $7.6 \pm 2.1 \%$. The Draken formation sample, $\mathrm{P} 4705-\mathrm{A}$, has a bulk $\delta^{34} \mathrm{~S}_{\mathrm{CRS}}$ value of $-28.0 \pm 0.2 \%$, a bimodal distribution of individual grain $\delta^{34} \mathrm{~S}$ values, a mean SIMS $\delta^{34} \mathrm{~S}$ value of $-34.6 \%$ o $(\sigma=15.9 \%, n=46)$, and an individual grain $\delta^{34} \mathrm{~S}$ range of $-61.0 \pm 4.4 \%$ o to $-6.4 \pm 1.9 \%$. The concentrations of CRS are $230 \pm 20$ ppm S in K95-101, $301 \pm 20$ ppm $\mathrm{S}$ in $\mathrm{K} 95-103$, and $516 \pm 20$ ppm S in P4705-A. Total organic carbon concentrations are $0.6 \pm 0.1 \mathrm{wt} \%$ in K95-101, $0.4 \pm 0.1 \mathrm{wt} \%$ in $\mathrm{K} 95$ 103 , and $0.2 \pm 0.1 \mathrm{wt} \%$ in P4705-A.

\section{4 | DISCUSSION}

\subsection{Fine-scale $\delta^{34} \mathrm{~S}$ trends}

These two sample suites were selected for their similar diagenetic histories of early dolomitization, silicification, and exceptional mat 

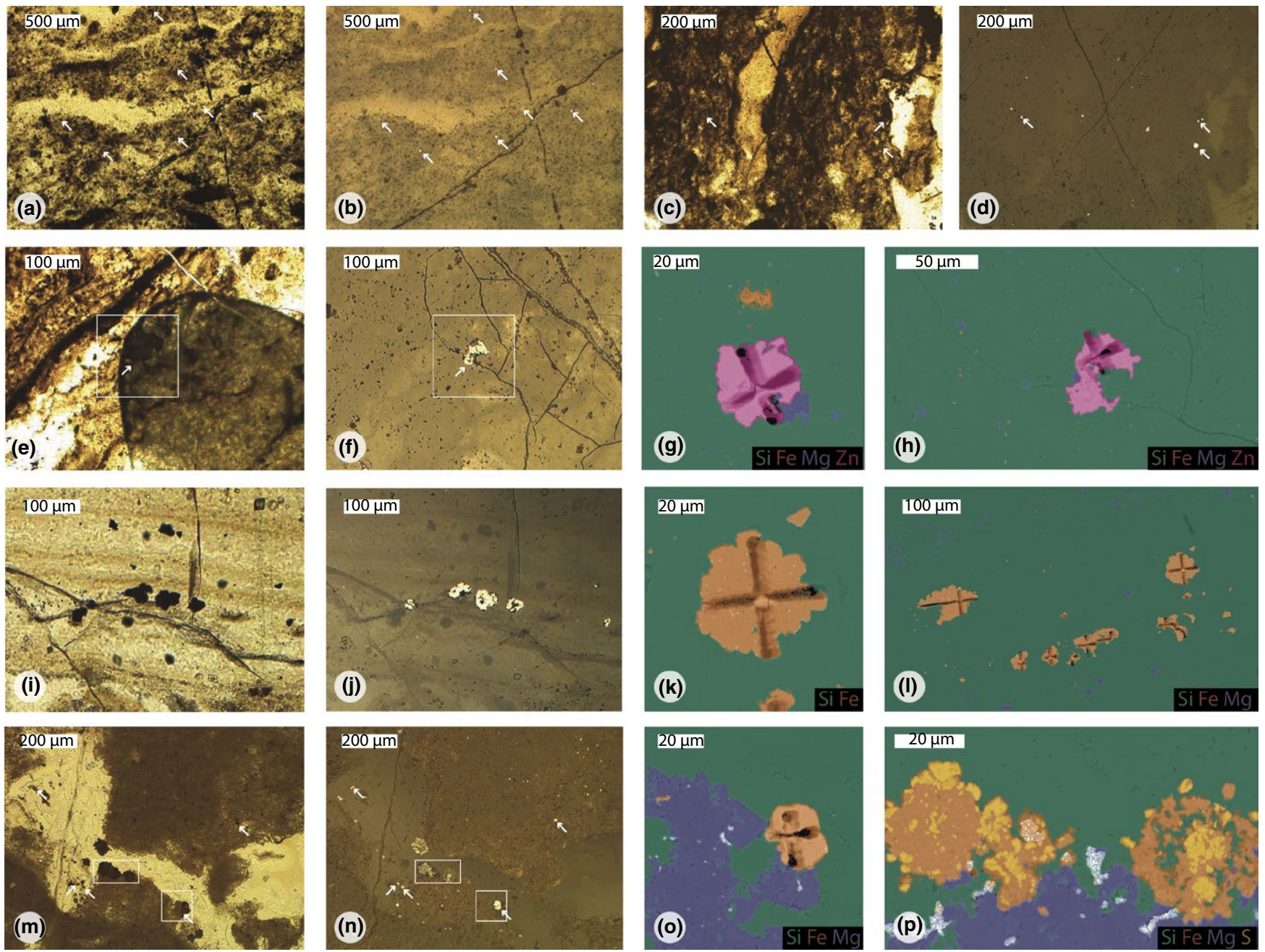

FIGURE 5 Images of cross-cutting relationships: (a,b) organic-rich mat textures in K95-101, (c,d) organic-rich mat textures in K95-103, (e-h) sphalerite grains in K95-103, (i-l) pyrite grains in a laminated silicified mat fragment in P4705, and ( $\mathrm{m}-\mathrm{p})$ pyrite grains at the boundary between silicified void spaces and organic-rich mat textures in P4705. Images (a), (c), (e), (i), and (m) are taken in plane-polarized light. Images (b), (d), (f), (j), and $(\mathrm{n})$ are taken in reflected light. Images in $(\mathrm{g}),(\mathrm{h}),(\mathrm{k}),(\mathrm{l}),(\mathrm{o})$, and $(\mathrm{m})$ are SEM images overlain by elemental maps, which show distributions of $\mathrm{Si}$ (green, indicating silicified material), Fe (orange, indicating pyrite in (g), (h), (k), (l), and (o) and iron oxides in (m), Mg (purple, indicating dolomite), Zn (pink, indicating sphalerite in (g, h)), and S (yellow, indicating pyrite in ( $\mathrm{m})$ ). Sulfide grains that have been analyzed by SIMS are indicated by white arrows in plane-polarized and reflected light images. The location of image $\mathrm{G}$ is indicated by the blue box in Figure $4 \mathrm{~d}$,e. The white box in (e) and (f) indicates the location of image (h). Images (k) and (I) show pyrite grains within the same silica-rich mat fragment shown in images (i) and (j) and is located $\sim 2 \mathrm{~mm}$ to the left of (i) and (j). The leftmost white box in ( $\mathrm{m}$ ) and (n) indicates the location of image (p). The rightmost white box in $(\mathrm{m})$ and $(\mathrm{n})$ indicates the location of image (o). Pits made by SIMS measurements are shown in (g), (h), (k), (I) and (o). Sample names for grains in SEM images are as follows: (g) K95-103-PYR14; (H) K95-103-PYR12; (k) P4705-A-PYR49 (top) and P4705-A-PYR50 (bottom); (I) left to right: P4705-A-PYR43, P4705-A-PYR44, P4705-A-PYR46, P4705-A-PYR45, P4705-A-PYR47, P4705-A-PYR48, P4705-A-PYR51, P4705A-PYR50, and P4705-A-PYR49; (o) P4705-A-PYR40; (m) left to right; P4705-A-PYR81 and P4705-A-PYR80

fabric preservation, as well as their moderate temperature history and lack of evidence for metasomatic alteration. Although separated in age, they sample comparable environments that underwent similar early diagenetic silicification and preservation of early pyrite. Fine-scale $\delta^{34} \mathrm{~S}$ analyses and petrographic observations of sulfide minerals reveal a well-defined relationship between populations of small versus large sulfide grains and $\delta^{34} S$ values (Figure 7). Smaller pyrite grains $(<25 \mu \mathrm{m})$, which are more common in organic-rich portions of mat fragments (Figures 4 and $5 a-d, m, n$ ), tend to have higher $\delta^{34} S$ values. Larger pyrite and sphalerite grains $(>25 \mu \mathrm{m})$, found along the boundaries of silicified pore spaces (Figure $5 e, f, m, n$ ) and in mat fragments that have been almost completely replaced by silica (Figure $5 \mathrm{i}, \mathrm{j}$ ), tend to have lower $\delta^{34} \mathrm{~S}$ values. These two groups of pyrite grains are reflected in the bimodal distribution of $\delta^{34} \mathrm{~S}$ values in the histogram of P4705-A (Figure 6c). The distribution of $\delta^{34} S$ values in the Sukhaya Tunguska Formation samples (Figure 6a,b) does not show a bimodal pattern because the number of large sulfide grains in the sample is small (i.e., one $>25 \mu \mathrm{m}$ pyrite grain was analyzed in K95-101 and three $>25 \mu \mathrm{m}$ sphalerite grains were analyzed in K95-103). We interpret the relationship between 
(a)

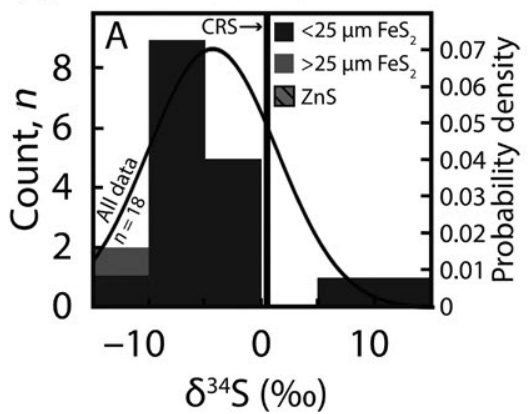

(b)

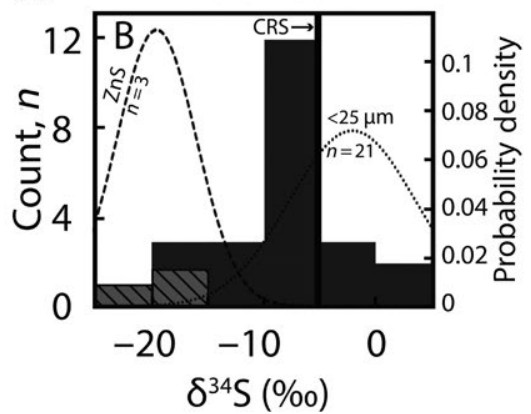

(c)

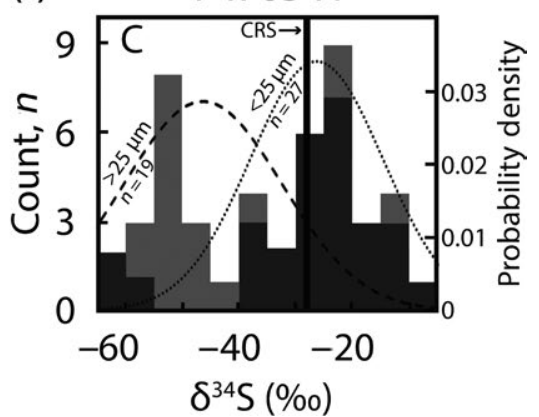

FIGURE 6 Frequency distribution of pyrite (FeS 2 ; gray bars) and zinc sulfide (ZnS; hatched gray bars) $\delta^{34} \mathrm{~S}$ values for (a) K95-101, (b) K95103, and (c) P4705-A. Bulk $\delta^{34} \mathrm{~S}$ values of chromium reducible sulfide (CRS) are indicated by the black bar. Probability density functions are shown for all data in K95-101 (a; solid line), $<25 \mu \mathrm{m} \mathrm{FeS}{ }_{2}$ in K95-103 (b; dotted line), ZnS in K95-103 (b; dashed line), <25 $\mu \mathrm{m}$ FeS 2 in P4705-A (c; dotted line), and $>25 \mu \mathrm{m} \mathrm{FeS} 2$ in P4705-A (c; dashed line)

$\delta^{34} \mathrm{~S}$ values in small versus large sulfide grains to reflect different generations of sulfide formation.

The small pyrite grains $(<25 \mu \mathrm{m})$ with relatively high $\delta^{34} \mathrm{~S}$ values represent one generation of sulfide formation. If we consider $\delta^{34} \mathrm{~S}_{\text {sulfide }}$ trends from modern microbial mats and consortia, where $\delta^{34} S_{\text {sulfide }}$ values tend to be higher near redox boundaries due to high average $\operatorname{cs} S R R$ and low $\varepsilon_{S R}$ values (i.e., the differential metabolic activity trend in Figure 1; Fike et al., 2008, 2009; Wilbanks et al., 2014), we could infer that these small pyrite grains represent a first generation of pyrite formation near the surface of the mat (i.e., location \#1 in Figure 1). However, high $\delta^{34} S_{\text {sulfide }}$ values also occur deeper within the sediments of many modern marine sedimentary environments (i.e., location \#2 in Figure 1) as a result of closed-system Rayleigh isotope effects during early diagenesis. Closed-system Rayleigh isotope fractionation trends have not been documented in modern marine microbial mats because sulfate concentrations are high (i.e., $>28 \mathrm{~mm}$ ) and only a small portion of the sulfate reservoir is consumed (<1\%; Fike et al., 2009). Similarly, incubations with low sulfate concentrations (0.2-1 $\mathrm{mm}$ ) using mat samples from modern marine environments did not show Rayleigh isotope fractionation trends. The lack of closed-system isotope effects was attributed to low rates of sulfide production (Fike et al., 2009), likely because the microbial communities in the mats were not adapted to low sulfate concentrations (Bradley et al., 2015). However, it is possible that the microbial mat communities associated with mat fragments in the studied samples were adapted to low sulfate conditions that were common in Proterozoic oceans (Canfield, 2004; Kah, Lyons, \& Frank, 2004) and therefore could consume a sufficiently large portion of the sulfate reservoir to generate a Rayleigh fractionation $\delta^{34} S_{\text {sulfide }}$ trend; such a pattern has been documented in late Archean sediments (Fischer et al., 2014). Thus, high $\delta^{34} \mathrm{~S}_{\text {sulfide }}$ values in the small pyrite grains could either capture the signature of sulfide near the redox boundary at the surface of the mat or at greater depths where a large fraction of the sulfate reservoir was consumed. It is also possible that high $\delta^{34} \mathrm{~S}$ values in the small pyrite grains reflect local microniches with variable but localized influences of Rayleigh isotope fractionation on $\delta^{34} \mathrm{~S}_{\text {sulfide }}$ values, which could occur at any depth in the mat.

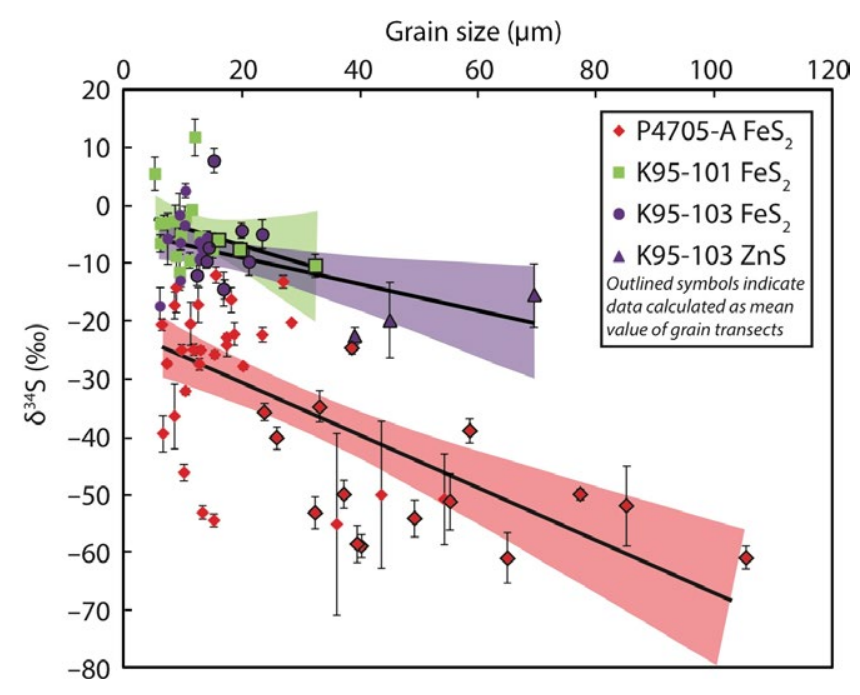

FIGURE 7 Grain size versus $\delta^{34} \mathrm{~S}$ values for $\mathrm{P} 4705-\mathrm{A}$ pyrite $\left(\mathrm{FeS}_{2}\right.$; red diamonds), K95-101 pyrite ( $\mathrm{FeS}_{2}$; green squares), K95-103 pyrite ( $\mathrm{FeS}_{2}$; purple circles), and K95-103 sphalerite (ZnS; purple triangles). Solid lines indicate the linear regression line, and shaded regions represent the $\pm 95 \%$ confidence interval

Using petrographic context and knowledge of pyrite formation mechanisms, we can attempt to differentiate between these two potential locations of small $(<25 \mu \mathrm{m})$ pyrite formation. First, the small pyrites are evenly disseminated in organic-rich groundmass with microtextures such as wavy crinkled laminae (Figures $4 d$,e, and $5 a-d)$ sponge pore fabrics (Figure $4 a, b, g, h$ ) and adjacent shrinkage cracks (Figure $5 \mathrm{a}-\mathrm{f}$ ) that are characteristic of microbially induced sedimentary structures (Noffke, 2009). Thus, although samples K95-101 and K95-103 come from a different formation than P4705-A, all of the studied samples show a petrographic association between small pyrite grains and organic-rich fragments with mat textures. Similar types of small pyrite grains in kerogen-rich matrix material in Archean microbial carbonates were interpreted to be early diagenetic pyrites (Kamber \& Whitehouse, 2007). The early diagenetic origin of the small pyrite grains in our samples is further 
supported by the excellent fabric retention and preservation of microfossils in both the Sukhaya Tunguska and Draken microbial mats, which suggests early diagenetic silicification and/or dolomitization (Mendelson \& Schopf, 1982; Fairchild et al., 1991; Knoll et al., 1991; Sergeev et al., 1997).

Second, empirical and theoretical studies of pyrite formation suggest that pyrite is formed near redox boundaries (Rickard, 1975; Wilkin, Barnes, \& Brantley, 1996; Wilkin, Arthur, \& Dean, 1997) and that small pyrite grains, in particular, are formed in locations with rapid redox oscillation (Wilkin et al., 1996). Therefore, it is likely that the early diagenetic, small pyrite grains were formed near the surface of the mat where diurnal cycles promote redox oscillation via vertical migration of the chemocline and the presence of intermediate sulfur species promotes pyrite formation. Biotic or abiotic (i.e., by reaction with $\mathrm{H}_{2} \mathrm{~S}$ ) reduction in iron oxides would also promote pyrite formation near the redox interface. It is possible that pyrite growth continued during burial upon the grains nucleated near the mat surface, and this may account for some of the inter- and intragrain range in the SIMS $\delta^{34} S$ values of the $<25 \mu \mathrm{m}$ pyrite grains. The intragrain $\delta^{34} \mathrm{~S}$ range could also reflect Rayleigh isotope effects occurring in microenvironments. We cannot completely rule out pyrite formation in deeper portions of the mat where $\delta^{34} \mathrm{~S}_{\text {sulfide }}$ values were high due to significant consumption of the sulfate reservoir. However, finely disseminated pyrite textures are believed to be the result of nucleation bursts and subsequent decreases in pyrite saturation (Rickard, 2012), which likely occurs in locations with frequent redox oscillations. Thus, based on these insights about how pyrite formation process impact pyrite textures and the association with organic-rich mat fragments (Figures 4 and $5 a-d, m, n)$, we posit that the small pyrite grains $(<25 \mu \mathrm{m})$ with high $\delta^{34} S_{\text {pyrite }}$ values were formed near a redox boundary (i.e., location \#1 in Figure 1). In this location, low apparent $\mathrm{S}$-isotope fractionations between sulfate and sulfide are a result of either high average csSRR associated with the respiration of photosynthetically produced labile organic matter and low sulfide concentrations due to active sulfide oxidation or Rayleigh isotope fractionation in microniches.

Large pyrite grains $(>25 \mu \mathrm{m})$ represent a different generation of sulfide formation in P4705-A, with lower $\delta^{34} \mathrm{~S}$ values than the small pyrites. The $\delta^{34} \mathrm{~S}$ value of the single $>25 \mu \mathrm{m}$ pyrite grain in $\mathrm{K} 95-101$ is also slightly lower $\left(-10.5 \pm 2.0 \%\right.$ o than the mean $\delta^{34} S$ value of the $<25 \mu \mathrm{m}$ pyrite grains $(-4.2 \%, \sigma=5.7 \%$ o, $n=17)$. Only a single $>25 \mu \mathrm{m}$ pyrite grain was observed, and therefore, we will focus this discussion on P4705-A, which has a more robust data set; however, we note that grain size and $\delta^{34} \mathrm{~S}$ trends in $\mathrm{K} 95-101$ are consistent with those observed in P4705-A. These large (>25 $\mu \mathrm{m})$ grains in P4705-A are located along the boundaries of silicified vugs or channels (Figure $5 m-p$ ) as well as channelized portions of silicified mat fragments (Figure $5 \mathbf{i}-\mathbf{l}$ ). The pore spaces are thought to form either as a result of primary porosity in the microbial mats or from the dissolution of precursor materials under the influence of meteoric or deep-burial fluids (Choquette \& Pray, 1970). While we cannot completely rule out the possibility that these grains formed during deep burial from hydrothermal (or other) fluids, their location along the edges of silicified void spaces and mat fragments implies their formation predates silicification.
It is also unlikely that these grains formed from hydrothermal fluids because the $\delta^{34} \mathrm{~S}$ values of the large $(>25 \mu \mathrm{m})$ pyrite grains are lower than hydrothermally derived sulfide (i.e., $1 \%$ to $3 \%$; Arthur, 2000) as well as the small pyrite grains, which could have served as a source of sulfide from dissolution in hydrothermal fluids. It is also possible that dissolution of pyrite in adjacent sediments could be a source of sulfide. However, fractures cross-cut the large pyrite grains (Figure 5i,j) and silicified pore spaces (Figure $5 \mathrm{~m}, \mathrm{n}$ ) and therefore postdate the formation of the large pyrite grains and silicified pore spaces. This implies that, if sulfide from adjacent sediments was transported through these fractures, it did not contribute to the formation of the large pyrite grains. Instead, it is likely that the large pyrite grains formed from early diagenetic pore fluids flowing though the vugs or channels at depth within the mat (i.e., location \#3 in Figure 1) or, in the case of reworked mat fragments, after the mats had been ripped up by storms and redeposited in more offshore settings. Additional support for a diagenetic rather than hydrothermal sulfide source is the excellent fabric retention and preservation of microfossils associated with these samples that indicates early dolomitization and silicification (Knoll et al., 1991; Fairchild et al., 1991). The refractory nature of organic carbon deep within the mat and/or entrained and redeposited mat fragments could lead to low average csSRR, resulting in high $\varepsilon_{S R}$ values and low $\delta^{34} S$ values. Nutrient limitation or co-limitation may also play a role in suppressing average csSRR (Bradley et al., 2015), but is not necessarily required to explain the fine-scale $\delta^{34} S$ patterns. In sum, the large pyrite grains tend to have lower $\delta^{34} S$ values because they record $\delta^{34} S$ values of sulfide produced at low average csSRR deep within sediments in locations exposed to fluids promoting pyrite formation.

The large $(>35 \mu \mathrm{m})$ sphalerite grains in K95-103 represent yet another stage of sulfide mineral formation. It is important to note that sphalerite grains were only detected in one sample, and therefore, we have only observed evidence for this stage of sulfide mineral growth in sample K95-103. In K95-103, the sphalerite grains are located along the edges of pore spaces (Figure $5 \mathrm{e}-\mathrm{h}$ ) and have low $\delta^{34} \mathrm{~S}$ values, while the smaller pyrite grains are evenly distributed in organic-rich mat fragments (Figures $4 d, e$ and $5 c, d$ ) and have higher $\delta^{34} S$ values. Pyrite and sphalerite have different thermodynamic relationships, reaction kinetics, and redox reaction pathways that influence how we interpret the $\delta^{34} \mathrm{~S}$ values of the sphalerite grains. In particular, sphalerite is thought to form prior to pyrite due to faster water exchange reaction kinetics associated with Zn (Morse \& Luther, 1999). Thus, we might expect that the sphalerite grains formed before both the small and the large pyrite grains. In fact, precipitation of sphalerite has been documented in modern biofilms (Labrenz et al., 2000) and these sphalerite grains share some characteristics with the sphalerite grains in K95-103. Sphalerite grains in the modern biofilms have microtextures formed by aggregation of smaller particles, are a few tens of micrometers in size, have spatially heterogeneous distribution patterns, and are found in organic-rich microenvironments (Druschel, Labrenz, Thomsen-Ebert, Fowle, \& Banfield, 2002). Yet, sphalerite grains are not found within the organic-rich mat fragments in K95-103. Instead, the sphalerite grains are primarily found along the boundary between organic-rich mat fragments and laminoid fenestrae (Figure $5 \mathrm{e}-\mathrm{h}$ ). 
Laminoid fenestrae are commonly formed in intertidal to supratidal settings from wetting and drying of microbial mats and/or carbonate mud that leads to separation of the mat surface from the adjacent sediment (Shinn, 1968; Davies, 1970; Logan, Hoffman, \& Gebelein, 1974; Hardie \& Ginsburg, 1977). Thus, the sphalerite grains likely formed as a result of diagenesis that occurred after the wet-dry cycles that led to the development of the laminoid fenestrae.

Shale and iron formation records suggest that Proterozoic marine zinc concentrations were similar to modern marine levels (Scott et al., 2013; Robbins et al., 2013), and so seawater zinc would be available for sphalerite formation. We do not find sphalerite grains finely dispersed in the organic-rich matrix materials, which necessarily formed prior to the development of laminoid fenestrae during desiccation. It is possible that organic complexation or microbial uptake of zinc in the mats depleted the porewaters of available zinc and inhibited the formation of zinc sulfides within the organic-rich matrix. Then, during the time periods between the re-wetting of the desiccated mat and the establishment of a new phototrophic microbial mat community, diminished zinc uptake by microorganisms allowed for higher concentrations of zinc. This laid the foundation for sphalerite formation along the boundary between fenestrae and organic-rich mat fragments that served as an organic carbon substrate for MSR. This would require a large quantity of zinc and therefore repeated wet-dry cycles or introduction of new zinc by flushing with seawater under continued wet conditions over a long time period before the re-establishment of phototrophic microbial mat communities. The formation during repeated wet and dry cycles is consistent with the large range of $\delta^{34} \mathrm{~S}$ values measured in sphalerite grain transects (i.e., up to $117.4 \%$; Table S1) because differential rates of MSR, diffusion and advection, evaporation and wetting (which would concentrate or dilute sulfate, sulfide, and zinc), and Rayleigh isotope fractionation in microenvironments would result in heterogeneous $\delta^{34} \mathrm{~S}_{\text {sulfide }}$ values over the course of mineral growth. Despite the large range of $\delta^{34} S$ values in sphalerite grain transects, mean $\delta^{34} S$ values of sphalerite grains are similar (Figure $6 \mathrm{~b}$ ). Thus, mean $\delta^{34} \mathrm{~S}$ values of sphalerite grains capture an integrated signal of this stage of sulfide growth in this sample. The heterogonous intragrain $\delta^{34} \mathrm{~S}$ values imply that microbial sulfate reducers were able to utilize organic carbon in the mat or entrained in fluids in previously desiccated mats to reduce sulfate to sulfide in an unsteady diagenetic regime.

Based on the hypothesized formation mechanisms for the different generations of sulfide minerals, we can draw some inferences about the environmental history of the microbialite samples and the $\delta^{34} \mathrm{~S}_{\text {sulfide }}$ signatures of each stage of sulfide formation. In this discussion, it is important to note that the lagoonal depositional setting of the microbial mats (i.e., prior to entrainment and redeposition) could have had varying degrees of connectivity with the ocean and/or rates of evaporation during the lifetime of the mat. Evaporation of water does not directly affect the isotopic composition of sulfate, but it does alter the size of the local sulfate reservoir. Enhanced evaporation of seawater would lead to higher sulfate concentrations and a decreased potential of Rayleigh isotope fractionation during MSR to drive sulfate to high $\delta^{34} S$ values. In contrast, the input of freshwater from land or precipitation would lead to lower sulfate concentrations and a greater potential for sulfate to become ${ }^{34} \mathrm{~S}$-enriched due to MSR. Or, put another way, $\delta^{34} S_{\text {sulfate }}$ values can vary to a greater extent when sulfate levels are low due to the dilution of seawater by freshwater or precipitation. In what follows, we take S-isotopic analyses of late Mesoproterozoic and early to mid-Neoproterozoic gypsum and anhydrite $\delta^{34}$ S values of ca. $20 \pm 5 \%$ o to approximate the isotopic composition of seawater sulfate (Kah, Lyons, \& Chesley, 2001; Canfield, 2004), but note that the sulfate concentration and potential for ${ }^{34} \mathrm{~S}$ enrichment in sulfate may vary as a function of lagoon hydrology, and this also has potential to affect $\delta^{34} \mathrm{~S}_{\text {pyrite }}$ values.

In K95-101, pyrite grains are predominantly small $(<25 \mu \mathrm{m})$ and have high $\delta^{34}$ S values $(-11.6 \pm 3.1 \%$ o to $11.7 \pm 3.2 \%$ o). We suggest that these grains capture the signature of sulfide near the redox boundary based on their even distribution in organic-rich mat fragments, excellent fabric retention, and preservation of microfossils in these samples that indicates early lithification (Mendelson \& Schopf, 1982; Fairchild et al., 1991; Knoll et al., 1991; Sergeev et al., 1997), and theoretical models of how environmental conditions influence pyrite morphology (Rickard, 2012). Although this sample could have gone through wetdry cycles and have been impacted by fluid flow during deep burial, we do not see petrographic evidence for sulfide formation during these stages. Thus, the bulk $\delta^{34} \mathrm{~S}_{\mathrm{CRS}}$ value of $\mathrm{K} 95-101$ records the $\delta^{34} \mathrm{~S}$ signature of pyrites formed adjacent to the redox boundary in the upper portions of the mat during early diagenesis. The $\delta^{34} \mathrm{~S}$ values of the majority of the individual pyrite grains are lower bulk $\delta^{34} \mathrm{~S}_{\mathrm{CRS}}$ value, which may indicate that the pyrite grains that were too small to be measured by our SIMS method (i.e., $<5 \mu \mathrm{m}$ ) have higher $\delta^{34} \mathrm{~S}$ values. The $\delta^{34} S$ range in individual pyrite grains of $23.3 \%$ could reflect localized Rayleigh isotope fractionation due to significant sulfate consumption during early diagenesis or heterogeneity of $\varepsilon_{S R}$ values in early diagenetic microniches in the upper portions of the mat environment. Considering the average of the small pyrite $\delta^{34} S$ values, the S-isotope difference between this small pyrite population and estimated coeval seawater sulfate is $24.5 \%$, which is similar to the $\mathrm{S}$-isotope difference between the bulk $\delta^{34} \mathrm{~S}_{\mathrm{CRS}}$ value and inferred coeval seawater sulfate (19.4\%o). This implies that, in absence of significant Rayleigh isotope fractionation of the overlying sulfate reservoir, the average S-isotope fractionation between sulfate and sulfide $\left(\Delta^{34} \mathrm{~S}\right)$ near the upper redox boundary was $\sim 20 \%$ in this 1,000 Ma microbial mat, which should be considered a minimum value because Rayleigh isotope fractionation in microenvironments would decrease the apparent $\delta^{34} \mathrm{~S}$ offset.

K95-103 contains both small $(<25 \mu \mathrm{m})$ pyrite grains and large $(>35 \mu \mathrm{m})$ sphalerite grains. Applying the criteria given in the previous paragraph for the formation of small pyrite grains in K95-101 to this sample, we similarly suggest that the small pyrite grains formed first near the redox boundary close to the mat surface. Subsequent wet-dry cycles lead to the establishment of laminoid fenestrae (Figure $5 \mathrm{e}-\mathrm{h}$ ) and subsequent formation of large sphalerite grains. The bulk $\delta^{34} \mathrm{~S}_{\mathrm{CRS}}$ value represents a mixed signal of two sulfide populations formed during different stages of diagenesis and is offset from the coeval seawater sulfate $\delta^{34} S$ value by $25.1 \%$. On its own, this bulk value may not be that meaningful because it does 
not represent a single stage of sulfide mineral formation. However, the fine-scale analyses allow us to demonstrate that the mean small pyrite $\delta^{34} S$ value is $27.1 \%$ lower than the estimated $\delta^{34} S$ value of coeval seawater sulfate. This value, which approximates the $\Delta^{34} \mathrm{~S}$ value near the upper redox boundary, is similar to the $\Delta^{34} \mathrm{~S}$ value of $24.5 \%$ determined for the other 1,000 Ma sample (K95-101). The mean sphalerite $\delta^{34} \mathrm{~S}$ value is $39.4 \%$ o lower than the estimated $\delta^{34} \mathrm{~S}$ value of coeval seawater sulfate. It is possible that the bulk $\delta^{34} \mathrm{~S}$ signature of these two sulfide populations could be determined from sequential extraction of sphalerite by acid extraction and pyrite by chromium reduction (see Morse \& Luther, 1999 for discussion). Unfortunately, there is no corresponding way to chemically separate different generations of pyrite grains. Nonetheless, sequential separation of these operationally defined sulfide pools could aid in distinguishing populations of sulfide minerals with distinct $\delta^{34} S$ values. Supplementing the sequential extraction with fine-scale analyses has the added benefit of connecting the different generations of sulfide mineral formations to the environmental history of the sample.

Lastly, P4705-A contains two generations of pyrite formation represented by small $(<25 \mu \mathrm{m})$ and large $(>25 \mu \mathrm{m})$ pyrite populations. Similar to the Sukhaya Tunguska samples, even distribution in mat fragments, retention of mat textures, and excellent microfossil preservation (Knoll et al., 1991) along with pyrite formation theory (Rickard, 2012) imply that small pyrite $\delta^{34} S$ values capture the $\delta^{34} S$ signature of sulfide adjacent to the redox boundary at the surface of the mat. In contrast, the observation that large pyrite grains occur along the edges of silicified void spaces implies that large pyrite $\delta^{34} S$ values reflect the $\delta^{34} S$ value of sulfide in pore fluids during later stages of burial or after entrainment of mat fragments and redeposition. These two populations are easily distinguished in the frequency distribution plot of SIMS $\delta^{34} \mathrm{~S}$ values (Figure 6c), and the bulk $\delta^{34} \mathrm{~S}_{\mathrm{CRS}}$ value represents an average of these two populations. While the bulk $\delta^{34} \mathrm{~S}_{\mathrm{CRS}}$ value is $48.0 \%$ lower than the estimated $\delta^{34} S$ value of coeval seawater sulfate, this $\mathrm{S}$-isotope difference is $46.4 \%$ ond $66.2 \%$ o for the small and large pyrite populations, respectively. The difference in apparent S-isotope fractionation between the small and the large pyrite grains could indicate two different paleoenvironmental trends: (i) If small pyrite grains were precipitated in the upper portions of the mat and large pyrite grains in deeper portions, then that would imply the $\delta^{34} \mathrm{~S}_{\text {sulfide }}$ gradient was similar to what is observed in modern microbial mats (Fike et al., 2008, 2009); (ii) if small pyrite grains were precipitated in the upper portions of the mat and large pyrite grains were precipitated after entrainment and redeposition, then the difference in apparent S-isotope fractionation could be due to different average cSSRR, different amounts of localized system openness, or differences in $\delta^{34} \mathrm{~S}$ values of the sulfate reservoir in lagoonal versus deeper water depositional settings. At this time, we are unable to differentiate between these options. This $750 \mathrm{Ma}$ sample has a higher $\Delta^{34} \mathrm{~S}$ value near the upper redox boundary than the $1000 \mathrm{Ma}$ samples, inferred from the mean $\delta^{34} \mathrm{~S}$ value of the small $(<25 \mu \mathrm{m})$ pyrite grains and assuming minimal influence of Rayleigh isotope fractionation on the overlying sulfate reservoir. This could be due to higher ambient sulfate concentrations, increasing $\varepsilon_{\mathrm{MSR}}$ and/or depressing closed-system behavior during MSR, enhanced oxidative S cycling, or differences in organic carbon and nutrient availability.

The inferred environmental histories of sulfide formation in these microbialite samples represent our best attempt to synthesize the information provided by petrography, elemental mapping, and fine-scale $\delta^{34} S$ analyses. We cannot completely rule out other processes. For example, closed-system Rayleigh isotope effects are likely influencing $\delta^{34} \mathrm{~S}$ values on a local scale, which can explain some of the $\delta^{34} \mathrm{~S}$ variability within both individual crystals and the small and large pyrite pools. However, we do not see evidence for significant pyrite formation in where $\delta^{34} S_{\text {sulfide }}$ values are very high due to consumption of the sulfate reservoir in a closed system (i.e., location \#2 in Figure 1) because petrographic evidence (Figure $4,5 a-d, m, n$ ) suggests that small pyrite grains are formed near the surface (i.e., location \#1 in Figure 1) and large pyrite grains (Figure $5 i-p$ ) are formed deeper in the mat where average csSRR are low (i.e., location \# 3 in Figure 1). Given that fluid inclusion data indicate marine sulfate levels, which were 50\%-90\% lower in the Proterozoic than modern sulfate concentrations (Lowenstein, Hardie, Timofeeff, \& Demicco, 2003; Spear et al., 2014), and organic carbon availability was high in these mats, we would expect near-complete consumption of the sulfate reservoir deep in the mat. If near-complete consumption of the sulfate reservoir did lead to high $\delta^{34} \mathrm{~S}_{\text {sulfide }}$ values at depth, this signature was not captured in the pyrite grains, perhaps because iron limitation inhibited significant pyrite formation in this location. Late-stage alteration also has the potential to affect $\delta^{34} S$ values. However, three observations imply that the effects of late-stage (i.e., catagenetic) alteration are minimal in our samples: (1) the lack of pyrite in veins or other alteration textures, (2) petrographic evidence that veins cross-cut sulfide grains and mat fragments (Figure 5), and (3) the excellent fabric retention and preservation of microfossils indicating early lithification. In sum, the textural and geochemical information provided by these techniques gives us confidence in our reconstructions of the evolution of sulfur cycling in these ancient microbial environments.

\subsection{Implications for the sedimentary sulfide sulfur isotope record}

The $\delta^{34} \mathrm{~S}$ record of sedimentary sulfides provides important information about the oxygenation of the ocean and atmosphere through Earth history (e.g., Canfield \& Farquhar, 2009; Figure 8). In particular, the increase in the range of $\delta^{34} S_{\text {pyrite }}$ values toward the present has been linked to oxygenation of Earth surface environments. There are two intriguing transitions: (i) at $\sim 2.4 \mathrm{Ga}$ the range of $\delta^{34} \mathrm{~S}$ values of sedimentary pyrites increases from $<\sim 20 \%$ to $\sim 50 \%$ and (ii) at roughly $635 \mathrm{Ma}$ there is another increase in the $\delta^{34} \mathrm{~S}_{\text {pyrite }}$ range. The first transition has been linked to the Great Oxidation Event and an associated increase in sulfate concentrations due to oxidative weathering of pyrite on land and/or a decrease in the efficiency of the pyrite burial sink due to diminished iron availability of the ocean. The second transition has been linked to the expansion of well-oxygenated environments through the oceans and associated biogeochemical changes that would increase the range of preserved $\delta^{34} S$ values, including 


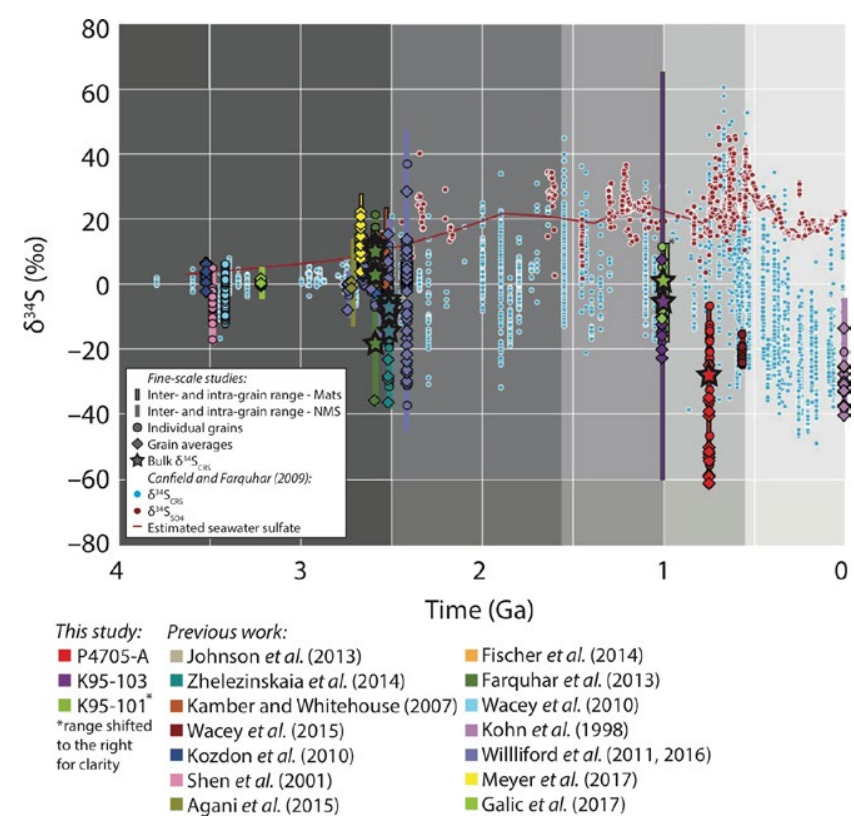

FIGURE 8 The sulfur isotope record of sedimentary pyrite (blue circles), sulfates (red circles), and reconstructed seawater sulfate (red line) from $4 \mathrm{Ga}$ to the present (Canfield \& Farquhar, 2009; modified from Fike et al., 2015). Superimposed on this long-term record is a compilation of sulfur isotope data from fine-scale studies: full inter- and intragrain ranges of $\delta^{34} \mathrm{~S}$ values of sulfide grains in samples with evidence for production in association with microbial mats or biofilms (outlined blocks), full inter- and intragrain ranges of $\delta^{34} \mathrm{~S}$ values of sulfide grains in samples where no evidence for production in association with microbial mats or biofilms was reported (i.e., normal marine sediments or NMS; blocks), individual $\delta^{34} S$ values of sulfide grains (outlined circles), average $\delta^{34} S$ values from intragrain measurements (outlined diamonds), and bulk $\delta^{34} S$ values of chromium reducible sulfide (CRS; stars). ${ }^{*} \delta^{34} S$ range of $\mathrm{K} 95-101$ shifted to the right for clarity

enhanced oxidative sulfur cycling and microbial disproportionation (Canfield \& Teske, 1996), decreased average csSRR, and/or increased system openness due to expanded aerobic respiration of more labile organic matter (Fike et al., 2015), or the physiologically related onset of bioturbation (Canfield \& Farquhar, 2009; Aller, 2014). These interpretations are consistent with other types of geological evidence that point to transitions in Earth surface oxygenation at $\sim 2.4 \mathrm{Ga}$ and $\sim 635 \mathrm{Ma}$. Yet, to a first order, this interpretation rests on the assumption that bulk $\delta^{34} S_{\text {CRS }}$ values represent an environmentally meaningful average of discrete $\delta^{34} S$ values from individual pyrite grains.

The data presented here and elsewhere indicate that the range of $\delta^{34} S$ values measured within a single sample can be as great as or larger than the range of bulk $\delta^{34} \mathrm{~S}_{\mathrm{CRS}}$ values observed globally for the same time interval (Figure 8 ) and may reflect different stages of sulfide mineral growth. The bulk $\delta^{34} \mathrm{~S}_{\mathrm{CRS}}$ value is thus a signal that integrates the isotopic signatures imprinted at different stages of pyrite (and other sulfide mineral) formation. Apparent secular variation in bulk $\delta^{34} S_{C R S}$ values may thus reflect shifts in the range of individual pyrite grain $\delta^{34} S$ values and/or changes in the proportion of sulfide grains formed at different stages of sulfide formation. In turn, these patterns will be influenced by the processes that are generally considered to impact bulk $\delta^{34} \mathrm{~S}_{\mathrm{CRS}}$ values, such as changes in sedimentation rate (Claypool, 2004; Pasquier et al., 2017), depositional environment, redox conditions, iron and organic carbon availability, or the size and isotopic composition of the seawater sulfate reservoir. The data presented here are consistent with fine-scale $\delta^{34} S_{\text {pyrite }}$ trends in Paleoproterozoic marine sediments (Williford, Van Kranendonk, Ushikubo, Kozdon, \& Valley, 2011 ) indicating that, on a fine scale, the increase in the range of $\delta^{34} \mathrm{~S}_{\text {pyrite }}$ values beyond $~ 50 \%$ occurs well before $635 \mathrm{Ma}$ (Figure 8). Yet, this range is not widely reflected in bulk $\delta^{34} S_{\text {pyrite }}$ values. This may be due to low marine sulfate concentrations that suppress the magnitude of the apparent sulfur isotope fractionation between sulfate and sulfide that is preserved in marine sediments (Gomes \& Hurtgen, 2013). Or it may be that the types of environments that favored low average csSRR, oxidative sulfur cycling, microbial disproportionation, or perhaps even bioturbation by benthic organisms were not significant enough globally to affect the sedimentary pyrite $\delta^{34} S$ record until after $\sim 635 \mathrm{Ma}$ (Fike et al., 2015). Ancient microbial mats and biofilms are poorly represented in the sedimentary sulfide $\delta^{34} \mathrm{~S}$ record (Canfield \& Farquhar, 2009; Figure 8). Future studies that compare bulk and fine-scale sedimentary sulfide $\delta^{34} \mathrm{~S}$ patterns in ancient microbial mats and biofilms to continental shelf or other types of marine sediments will provide insight into the important preservational biases that influence $\delta^{34} S$ patterns in different depositional environments. Studies of bulk and fine-scale $\delta^{34} S$ trends in the context of petrographic observations that provide information about different generations of sulfide formation will further contribute to our knowledge of the evolution of redox conditions throughout the Proterozoic and other periods in Earth history.

More generally, on the time scale sampled in many geological investigations (i.e., tens of thousands of years to hundreds of millions of years) bulk $\delta^{34} \mathrm{~S}_{\mathrm{CRS}}$ values preserve broad signals of environmental change. However, because bulk $\delta^{34} \mathrm{~S}_{\mathrm{CRS}}$ values integrate many biogeochemical processes, the application of fine-scale geochemical and petrological methods to discern different generations of metal sulfide formation is key to interpreting these records. S-isotopes do suggest significant differences between our $1000 \mathrm{Ma}$ and $750 \mathrm{Ma}$ samples, whether viewed in terms of bulk or fine-scale analyses. Fine-scale $\delta^{34} S_{\text {pyrite }}$ studies serve as a useful complement to disentangle $\delta^{34} S_{\text {pyrite }}$ signatures associated with different stages of pyrite growth that can be used to extract additional paleoenvironmental information from geological materials. Thus, the combination of bulk and fine-scale geochemical analyses with petrographic observations allows us to better interpret the marine sedimentary record in order to explore the coupled evolution of life and the Earth surface system.

\section{5 | CONCLUSION}

Fine-scale $\delta^{34} \mathrm{~S}$ patterns in sulfide minerals can reveal information about variable environmental conditions and differential metabolic activity of microbial communities present at different depths in ancient microbial mats. We examined microbialite samples from two 
Proterozoic formations to evaluate whether fine-scale $\delta^{34} \mathrm{~S}_{\text {sulfide }}$ patterns in modern microbial mats and consortia are preserved in the geological record. We also explored how closed-system Rayleigh isotope fractionation or post-depositional alteration influence finescale $\delta^{34} \mathrm{~S}_{\text {pyrite }}$ patterns. We find that small $(<25 \mu \mathrm{m})$ pyrite grains tend to have higher $\delta^{34} S$ values than large $(>25 \mu \mathrm{m})$ pyrite and $(>35 \mu \mathrm{m})$ sphalerite grains. Based on these patterns, elemental mapping, petrographic information, and comparison with modern microbial mats, we suggest that there are three generations of sulfide formation in the studied samples: (i) small $(<25 \mu \mathrm{m})$ pyrite grains that formed near the redox interface with high $\delta^{34} S$ values due to high average csSRR, (ii) large $(>35 \mu \mathrm{m})$ sphalerite grains with low $\delta^{34} S$ values formed during repeated wet-dry cycles from sulfide produced by MSR under an unsteady diagenetic regime (i.e., variable rates of csSRR, diffusion, and advection), and (iii) large (>25 $\mu \mathrm{m})$ pyrite grains formed during later stages of burial with low $\delta^{34} S$ values due to formation from a pool of sulfide produced by slower average csSRR. Each sample contains grains from one or two of these stages of sulfide growth. Bulk $\delta^{34} S_{\text {pyrite }}$ values reflect a weighted average of the different sulfide groups. Fine-scale isotopic studies coupled with elemental mapping and petrographic observations can thus reveal important information about microbially mediated reactions occurring at different stages of burial. The extension of this approach to other time periods and sedimentary materials will enhance our ability to extract paleoenvironmental information from the geological record.

\section{CONFLICT OF INTEREST}

The authors declare no conflict of interest.

\section{ACKNOWLEDGMENTS}

The authors thank the NASA Astrobiology Institute, Washington University, and Massachusetts Institute of Technology (MIT) as well as the NSF Major Research Instrumentation (EAR \#1229370) and DOE/BER Bioimaging Technology (DE-SC0014613) awards to DAF for supporting this work. We are also grateful for the technical support of Nilanjan Chatterjee (MIT) for electron microprobe analyses, Erin Beirne (Harvard University) for isotope ratio mass spectroscopy measurement, Stephanie Moore (Washington University) for carbon concentration analyses, Michael Krawczynski (Washington University) for access to petrographic microscopes, and Harry-Luke McClelland (Washington University) for help constructing figures. We thank David Johnston, Andrew Masterson (Harvard), Jennifer Houghton, and Jocelyn Richardson (Washington University) for comments that improved the manuscript.

\section{REFERENCES}

Aller, R. C. (2014). Sedimentary diagenesis, depositional environments, and benthic fluxes. In H. D. Holland, \& K. K. Turekian (Eds.), Treatise on geochemistry, Vol. 8 (pp. 293-334). Oxford: Elsevier.

Aller, R. C., Madrid, V., Chistoserdov, A., Aller, J. Y., \& Heilbrun, C. (2010). Unsteady diagenetic processes and sulfur biogeochemistry in tropical deltaic muds: Implications for oceanic isotope cycles and the sedimentary record. Geochimica et Cosmochimica Acta, 74, 4671-4692.

Anbar, A. D., \& Knoll, A. H. (2002). Proterozoic ocean chemistry and evolution: A bioinorganic bridge? Science, 297, 1137-1142.

Arthur, M. A. (2000). Volcanic contributions to the carbon and sulfur geochemical cycles and global change. Encyclopedia of Volcanoes (pp. 1045-1056). Cambridge, MA: Academic.

Bartley, J. K., Semikhatov, M. A., Kaufman, A. J., Knoll, A. H., Pope, M. C., \& Jacobsen, S. B. (2001). Global events across the MesoproterozoicNeoproterozoic boundary: $\mathrm{C}$ and $\mathrm{Sr}$ isotopic evidence from Siberia. Precambrian Research, 111, 165-202.

Bradley, A. S., Leavitt, W. D., Schmidt, M., Knoll, A. H., Girguis, P. R., \& Johnston, D. T. (2015). Patterns of sulfur isotope fractionation during microbial sulfate reduction. Geobiology, 14(1), 91-101.

Bruchert, V., \& Pratt, L. M. (1996). Contemporaneous early diagenetic formation of organic and inorganic sulfur in estuarine sediments from St. Andrew Bay, Florida, USA. Geochimica et Cosmochimica Acta, 60, 2325-2332.

Canfield, D. E. (1991). Sulfate reduction in deep-sea sediment. American Journal of Science, 291, 177-188.

Canfield, D. E. (2004). The evolution of the Earth surface sulfur reservoir. American Journal of Science, 304, 839-861.

Canfield, D. E., \& Des Marais, D. J. (1993). Biogeochemical cycles of carbon, sulfur, and free oxygen in a microbial mat. Geochimica et Cosmochimica Acta, 57, 3971-3984.

Canfield, D. E., \& Farquhar, J. (2009). Animal evolution, bioturbation, and the sulfate concentration of the oceans. Proceedings of the National Academy of Science, 106, 8123-8127.

Canfield, D. E., Farquhar, J., \& Zerkle, A. L. (2010). High isotope fractionations during sulfate reduction in a low-sulfate euxinic ocean analog. Geology, 38(5), 415-418.

Canfield, D. E., Raiswell, R. R., \& Bottrell, S. H. (1992). The reactivity of sedimentary iron minerals towards sulfide. American Journal of Science, 292, 659-683.

Canfield, D. E., Raiswell, R. R., Westrich, J. T., Reaves, C. M., \& Berner, R. A. (1986). The use of chromium reduction in the analysis of reduced inorganic sulfur in sediments and shales. Chemical Geology, 54, 149-155.

Canfield, D. E., \& Teske, A. (1996). Late Proterozoic rise in atmospheric oxygen concentration inferred from phylogenetic and sulphur-isotope studies. Nature, 382, 127-132.

Chambers, L. A., Trudinger, P. A., Smith, J. W., \& Burns, M. S. (1975). Fractionation of sulfur isotopes by continuous cultures of Desulfovibrio desulfuricans. Canadian Journal of Microbiology, 10, 1602-1607.

Chanton, J. P., Martens, C. S., \& Goldhaber, M. B. (1987). Biogeochemical cycling in an organic-rich coastal marine basin. 8. A sulfur isotopic budget balanced by differential diffusion across the sediment-water interface. Geochimica et Cosmochimica Acta, 51, 1201-1208.

Choquette, P. W., \& Pray, L. C. (1970). Geologic nomenclature and classification of porosity in sedimentary carbonates. AAPG Bulletin, 54, 207-250.

Claypool, G. E. (2004). Ventilation of marine sediments indicated by depth profiles of pore water sulfate and b'34S. In R. J. Hill, J. Leventhal, Z. Aizenshtat, M. J. Baedecker, G. Claypool, R. Eganhouse, M. B. Goldhaber, $\&$ K. Peters (Eds.), Geochemical investigations in Earth and Space science: A tribute to Isaac R. Kaplan, Vol. 9 (pp. 59-65). Amsterdam: Elsevier.

Cline, J. D. (1969). Spectrophotometric determination of hydrogen sulfide in natural waters. Limnology and Oceanography, 14, 454-458.

Dale, A. W., Bruchert, V., Alperin, M., \& Regnier, P. (2009). An integrated sulfur isotope model for Namibian shelf sediments. Geochimica et Cosmochimica Acta, 73, 1924-1944.

Davies, G. R. (1970). Carbonate bank sedimentation, eastern Shark Bay, Western Australia. American Association of Petroleum Geologists Memoir, 75, 85-168.

Druschel, G. K., Labrenz, M., Thomsen-Ebert, T., Fowle, D. A., \& Banfield, J. F. (2002). Geochemical modeling of ZnS in Biofilms: An example of ore depositional processes. Economic Geology, 97, 1319-1329. 
Fairchild, I. J., Bonnand, P., Davies, T., Fleming, E. J., Grassineau, N., Halverson, G. P., ... Stevenson, C. T. E. (2016). The late Cryogenian warm interval, NE Svalbard: Chemostratigraphy and genesis. Precambrian Research, 281, 128-154.

Fairchild, I. J., Knoll, A. H., \& Swett, K. (1991). Coastal lithofacies and biofacies associated with syndepositional dolomitization and silicification (Draken Formation, Upper Riphean, Svalbard). Precambrian Research, 53, 165-197.

Farquhar, J., Cliff, J., Zerkle, A. L., Kamyshny, A., Poulton, S. W., Claire, M., ... Harms, B. (2013). Pathways for Neoarchean pyrite formation constrained by mass-independent sulfur isotopes. Proceedings of the National Academy of Science, 110, 17638-17643.

Fike, D. A., Bradley, A. S., \& Rose, C. V. (2015). Rethinking the ancient sulfur cycle. Annual Review of Earth and Planetary Sciences, 43(1), 593-622.

Fike, D. A., Finke, N., Zha, J., Blake, G., Hoehler, T. M., \& Orphan, V. J. (2009). The effect of sulfate concentration on (sub)millimeter-scale sulfide $834 \mathrm{~S}$ in hypersaline cyanobacterial mats over the diurnal cycle. Geochimica et Cosmochimica Acta, 73, 6187-6204.

Fike, D. A., Gammon, C. L., Ziebis, W., \& Orphan, V. J. (2008). Micron-scale mapping of sulfur cycling across the oxycline of a cyanobacterial mat: A paired nanoSIMS and CARD-FISH approach. ISME Journal, 2(7), 749-759.

Firsching, F. H. (1961). Precipitation of silver phosphate from homogeneous solution. Analytical Chemistry, 33, 873-874.

Fischer, W. W., Fike, D. A., Johnson, J. E., Raub, T. D., Guan, Y., \& Kirschvink, J. L. (2014). SQUID-SIMS is a useful approach to uncover primary signals in the Archean sulfur cycle. Proceedings of the National Academy of Science, 111, 5468-5473.

Frolov, S. V., Akhmanov, G. G., Bakay, E. A., Lubnina, N. V., Korobova, N. I., Karnyushina, E. E., \& Kozlova, E. V. (2015). Meso-Neoproterozoic petroleum systems of the Eastern Siberian sedimentary basins. Precambrian Research, 259, 95-113.

Fry, B., Gest, H., \& Hayes, J. M. (1988). 34S/32S fractionation in sulfur cycles catalyzed by anaerobic bacteria. Applied and Environmental Microbiology, 54(1), 250-256.

Goldhaber, M. B., \& Kaplan, I. R. (1975). Controls and consequences of sulfate reduction rates in recent marine sediments. Soil Science, 119(1), 42-55.

Gomes, M. L., \& Hurtgen, M. T. (2013). Sulfur isotope systematics of a euxinic, low-sulfate lake: Evaluating the importance of the reservoir effect in modern and ancient oceans. Geology, 41(6), 663-666.

Gomes, M. L., \& Hurtgen, M. T. (2015). Sulfur isotope fractionation in modern euxinic systems: Implications for paleoenvironmental reconstructions of paired sulfate-sulfide isotope records. Geochimica et Cosmochimica Acta, 157, 39-55.

Gorokhov, I. M., Semikhatov, M. A., Baskakov, A. V., Kutyavin, E. P., Mel'nikov, N. N., Sochava, A. V., \& Turchenko, T. L. (1995). Sr isotopic composition in Riphean, Vendian, and Lower Cambrian Carbonates from Siberia. Stratigraphy and Geological Correlation, 3, 1-28.

Grotzinger, J. P., \& Knoll, A. H. (1999). Stromatolites in Precambrian carbonates: Evolutionary mileposts or environmental dipsticks?. Annual Review of Earth and Planetary Sciences, 27, 313-358.

Habicht, K. S., \& Canfield, D. E. (1996). Sulphur isotope fractionation in modern microbial mats and the evolution of the sulphur cycle. Nature, 382, 342-343.

Habicht, K. S., \& Canfield, D. E. (2001). Isotope fractionation by sulfatereducing natural populations and the isotopic composition of sulfide in marine sediments. Geology, 29, 555-558.

Habicht, K. S., Gade, M., Thamdrup, B., Berg, P., \& Canfield, D. E. (2002). Calibration of sulfate levels in the Archean ocean. Science, 298(5602), 2372-2374.

Halverson, G. P. (2011). Glacial sediments and associated strata of the Polarisbreen Group, northeastern Svalbard. Memoirs of the Geological Society of London, 36, 571-579.

Halverson, G. P., Hoffman, P. F., Schrag, D. P., Maloof, A. C., \& Rice, A. H. N. (2005). Toward a Neoproterozoic composite carbon-isotope record: GSA. Bulletin, 117, 1181-1207.
Halverson, G. P., Wade, B. P., Hurtgen, M. T., \& Barovich, K. M. (2010). Neoproterozoic chemostratigraphy. Precambrian Research, 182, 337-350.

Hardie, L. A., \& Ginsburg, R. N. (1977). Layering: The origin and environmental significance of lamination and thin bedding. In L. A. Hardie (Ed.), Sedimentation on the modem Carbonate Tidal Flats of Northwest Andros Island, Bahamas (pp. 50-123). Baltimore: The Johns Hopkins University Press.

Harrison, A. G., \& Thode, H. G. (1958). Mechanism of the bacterial reduction of sulphate from isotope fractionation studies. Transactions of the Faraday Society, 54(1), 84-92.

Hartmann, M., \& Nielsen, H. (1968). 834 S-Werte in rezenten Meeressedimenten und ihre Deutung am Beispiel einiger Sedimentprofile aus der westlichen Ostsee. Geologische Rundschau, 58(2), 621-655. (Translated in Environmental and Health Studies, 648, 627-632).

Hayes, J. M., \& Waldbauer, J. R. (2006). The carbon cycle and associated redox processes through time. Philosophical Transactions of the Royal Society B, 631, 931-950.

Hoehler, T. M., Bebout, B. M., \& Des Marais, D. J. (2001). The role of microbial mats in the production of reduced gases on the early Earth. Nature, 412, 324-327.

Hoffman, P. F., Halverson, G. P., Domack, E. W., Maloof, A. C., SwansonHysell, N. L., \& Cox, G. M. (2012). Cryogenian glaciations on the southern tropical paleomargin of Laurentia (NE Svalbard and East Greenland), and a primary origin for the upper Russøya (Islay) carbon isotope excursion. Precambrian Research, 206-207, 137-158.

Ivanov, M. V., Gogotova, G. I., Matrosov, A. G., \& Zyakun, A. M. (1977). Fractionation of sulfur isotopes by phototrophic sulfur bacteria Ectothiorhodospira shaposhnikovii. Microbiology (English Translation Mikrobiologiya), 45, 655-659.

Johnson, J. E., Webb, S. M., Thomas, K., Ono, S., Kirschvink, J. L., \& Fischer, W. W. (2013). Manganese-oxidizing photosynthesis before the rise of cyanobacteria. Proceedings of the National Academy of Science, 110, 11238-11243.

Jorgensen, B. B. (1982). Mineralization of organic matter in the seabedthe role of sulphate reduction. Nature, 296, 643-645.

Kah, L. C., Lyons, T. W., \& Chesley, J. T. (2001). Geochemistry of a $1.2 \mathrm{Ga}$ carbonate-evaporite succession, northern Baffin and Bylot Islands: Implications for Mesoproterozoic marine evolution. Precambrian Research, 111, 203-234.

Kah, L. C., Lyons, T. W., \& Frank, T. D. (2004). Low marine sulphate and protracted oxygenation of the Proterozoic biosphere. Nature, 431, 834-838.

Kamber, B. S., \& Whitehouse, M. J. (2007). Micro-scale sulphur isotope evidence for sulphur cycling in the late Archean shallow ocean. Geobiology, 5, 5-17.

Kaplan, I. R., \& Rafter, T. A. (1958). Fractionation of stable isotopes of sulfur by Thiobacilli. Science, 127, 517-518.

Kaplan, I. R., \& Rittenberg, S. C. (1964). Microbiological fractionation of sulphur isotopes. Journal of General Microbiology, 34, 195-212.

Karlstrom, K. E., Bowring, S. A., Dehler, C. M., Knoll, A. H., Porter, S. M., Marais, D. J. D., ... Davidek, K. L. (2000). Chuar Group of the Grand Canyon: Record of breakup of Rodinia, associated change in the global carbon cycle, and ecosystem expansion by 740 Ma. Geology, 28, 619-622.

Knoll, A. H., Fairchild, I. J., \& Swett, K. (1993). Calcified microbes in Neoproterozoic carbonates: Implications for our understanding of the Proterozoic/Cambrian transition. Palaios, 8, 512-525.

Knoll, A. H., \& Swett, K. (1990). Carbonate deposition during the late Proterozoic era: An example from Spitsbergen. American Journal of Science, 290-A, 104-132.

Knoll, A. H., Swett, K., \& Mark, J. (1991). Paleobiology of a Neoproterozoic tidal flat/Lagoonal complex: The Draken Conglomerate Formation, Spitsbergen. Journal of Paleontology, 65, 531-570. 
Kohn, M. J., Riciputi, L. R., Stakes, D., \& Orange, D. L. (1998). Sulfur isotope variability in biogenic pyrite: Reflections of heterogeneous bacterial colonization? American Mineralogist, 83, 1454-1468.

Kozdon, R., Kita, N. T., Huberty, J. M., Fournelle, J. H., Johnson, C. A., \& Valley, J. W. (2010). In situ sulfur isotope analysis of sulfide minerals by SIMS: Precision and accuracy, with application to thermometry of 3.5 Ga Pilbara cherts. Chemical Geology, 275, 243-253.

Labrenz, M., Druschel, G. K., Thomsen-Ebert, T., Gilbert, B., Welch, S. A., Kemner, K. M., ... Banfield, J. F. (2000). Formation of sphalerite (ZnS) deposits in natural biofilms of sulfate-reducing bacteria. Science, 290 , 1744-1747.

Leavitt, W. D., Halevy, I., Bradley, A. S., \& Johnston, D. T. (2013). Influence of sulfate reduction rates on the Phanerozoic sulfur isotope record. Proc Natl Acad Sci U S A, 110(28), 11244-11249.

Lehnert, O., Stouge, S., \& Brandl, P. A. (2013). Conodont biostratigraphy in the Early to Middle Ordovician strata of the Oslobreen Group in Ny Friesland, Svalbard: German. Journal of Geosciences, 164, 149-172.

Logan, B. W., Hoffman, P., \& Gebelein, C. D. (1974). Algal mats, cryptalgal fabrics, and structures, Hamelin Pool, Western Australia. American Association of Petroleum Geologists Memoir, 22, 140-191.

Lowenstein, T. K., Hardie, L. A., Timofeeff, M. N., \& Demicco, R. V. (2003). Secular variation in seawater chemistry and the origin of calcium chloride basinal brines. Geology, 31(10), 857-860.

Lyons, T. W. (1997). Sulfur isotopic trends and pathways of iron sulfide formation in upper Holocene sediments of the anoxic Black Sea. Geochimica et Cosmochimica Acta, 61, 3367-3382.

Mendelson, C. V., \& Schopf, J. W. (1982). Proterozoic microfossils from the Sukhaya Tunguska, Shorikha, and Yudoma Formations of the Siberian Platform, U.S.S.R. Journal of Paleontology, 56, 42-83.

Meyer, N. R., Zerkle, A. L., \& Fike, D. A. (2017). Sulphur cycling in a Neoarchaean microbial mat. Geobiology, 15(3), 353-365.

Morse, J. W., \& Luther, G. W. (1999). Chemical influences on trace metalsulfide interactions in anoxic sediments. Geochimica et Cosmochimica Acta, 63, 3373-3378.

Nikishina, A. M., Sobornov, K. O., Prokopiev, A. V., \& Frolov, S. V. (2010). Tectonic evolution of the Siberian platform during the Vendian and Phanerozoic. Moscow University Geology Bulletin, 65, 1-16.

Noffke, N. (2009). The criteria for the biogeneicity of microbially induced sedimentary structures (MISS) in Archean and younger, sandy deposits. Earth-Science Reviews, 96, 173-180.

Ovchinnikova, G. V., Semikhatov, M. A., Gorokhov, I. M., Belyatskii, B. V., Vasilieva, I. M., \& Levskii, L. K. (1995). U-Pb systematics of PreCambrian carbonates: The Riphean Sukhaya Tunguska formation in the Turukhansk Uplift, Siberia. Lithology and Mineral Resources, 30, 525-536.

Pasquier, V., Sansjofre, P., Rabineau, M., Révillon, S., Houghton, J., \& Fike, D. (2017). Pyrite sulphur isotopes reveal glacial-interglacial environmental changes. Proceedings of the National Academy of Science., 114, 5941-5945.

Petrov, P. Y. (1993). Depositional environments of the lower formations of the Riphean Sequence, northern part of the Turukhansk Uplift, Siberia. Stratigraphy and Geological Correlation, 1, 181-191.

Petrov, P. Y., Semikhatov, M. A., \& Sergeev, V. N. (1995). Development of the Riphean carbonate platform and distribution of silicified microfossils: The Sukhaya Tunguska Formation, Turukhansk Uplift, Siberia. Stratigraphy and Geological Correlation, 3, 79-99.

Pope, M. C., Bartley, J. K., Knoll, A. H., \& Petrov, P. Y. (2003). Molar tooth structures in calcareous nodules, early Neoproterozoic Burovaya Formation, Turukhansk region, Siberia. Sedimentary Geology, 158, 235-248.

Porter, S. M., Meisterfeld, R., \& Knoll, A. H. (2003). Vase-shaped microfossils from the Neoproterozoic Chuar Group, Grand Canyon: A classification guided by modern testate amoebae. Journal of Paleontology, 77, 409-429.

Poser, A., Vogt, C., Knoller, K., Ahlheim, J., Weiss, H., Kleinsteuber, S., \& Richnow, H. H. (2014). Stable sulfur and oxygen isotope fractionation of anoxic sulfide oxidation by two different enzymatic pathways. Environmental Science and Technology, 48(16), 9094-9102.

Raven, M. R., Sessions, A. L., Fischer, W. W., \& Adkins, J. F. (2016). Sedimentary pyrite d34S differs from porewater sulfide in Santa Barbara Basin: Proposed role of organic sulfur. Geochimica et Cosmochimica Acta, 186, 120-134.

Rickard, D. T. (1975). Kinetics and mechanism of pyrite formation at low temperatures. American Journal of Science, 275, 636-652.

Rickard, D. T. (2012). Sulfidic sediments and sedimentary rocks. Oxford: Elsevier.

Robbins, L. J., Lalonde, S. V., Saito, M. A., Planavsky, N. J., Mloszewska, A. M., Pecoits, E., ... Konhauser, K. O. (2013). Authigenic iron oxide proxies for marine zinc over geological time and implications for eukaryotic metallome evolution. Geobiology, 11, 295-306.

Rooney, A. D., Strauss, J. V., Brandon, A. D., \& Macdonald, F. A. (2015). A Cryogenian chronology: Two long-lasting synchronous Neoproterozoic glaciations. Geology, 43, 459-462.

Scott, C., Planavsky, N. J., Dupont, C. L., Kendall, B., Gill, B., Robbins, L. J., ... Lyons, T. W. (2013). Bioavailability of zinc in marine systems through time. Nature Geoscience, 6, 125-128.

Semikhatov, M. A., Ovchinnikova, G. V., Gorokhov, I. M., Kuznetsov, A. B., Vasil'eva, I. M., Gorokhovskii, B. M., \& Podkovyrov, V. N. (2000). Isotope Age of the Middle-Upper Riphean Boundary: Pb-Pb Geochronology of the Lakhanda Group Carbonates, Eastern Siberia. Doklady Earth Sciences, 372, 625-629.

Sergeev, V. N., Knoll, A. H., \& Petrov, P. Y. (1997). Paleobiology of the Mesoproterozoic-Neoproterozoic transition: The Sukhaya Tunguska Formation, Turukhansk Uplift, Siberia. Precambrian Research, 85, 201-239.

Shen, Y., Buick, R., \& Canfield, D. E. (2001). Isotopic evidence for microbial sulphate reduction in the early Archaean era. Nature, 410, 77-81.

Shinn, E. A. (1968). Practical significance of birds eye structures in carbonate rocks. Journal of Sedimentary Petrology, 38, 215-223.

Sim, M. S., Bosak, T., \& Ono, S. (2011). Large sulfur isotope fractionation does not require disproportionation. Science, 333, 74-77.

Sim, M. S., Ono, S., Donovan, K., Templer, S. P., \& Bosak, T. (2011). Effect of electron donors on the fractionation of sulfur isotopes by a marine Desulfovibrio sp. Geochimica et Cosmochimica Acta, 75, 4244-4259.

Spear, N., Holland, H. D., Garcia-Veígas, J., Lowenstein, T. K., Giegengack, R., \& Peters, H. (2014). Analyses of fluid inclusions in Neoproterozoic marine halite provide oldest measurement of seawater chemistry. Geology, 42(2), 103-106.

Strauss, J. V., Rooney, A. D., Macdonald, F. A., Brandon, A. D., \& Knoll, A. H. (2014). 740 Ma vase-shaped microfossils from Yukon, Canada: Implications for Neoproterozoic chronology and biostratigraphy. Geology, 42, 659-662.

Valley, J. W., \& Kita, N. T. (2009). In situ oxygen isotope geochemistry by Ion Microprobe. Mineralogical Association of Canada Short Course, 41, 19-63.

Wacey, D., Kilburn, M. R., Saunders, M., Cliff, J. B., Kong, C., Liu, A. G., ... Brasier, M. D. (2015). Uncovering framboidal pyrite biogenicity using nano-scale CNorg mapping. Geology, 43(1), 27-30.

Wacey, D., McLoughlin, N., Whitehouse, M. J., \& Kilburn, M. R. (2010). Two coexisting sulfur metabolisms in a ca. 3,400 Ma sandstone. Geology, 38, 1115-1118.

Wilbanks, E. G., Jaekel, U., Salman, V., Humphrey, P. T., Eisen, J. A., Facciotti, M. T., ... Orphan, V. J. (2014). Microscale sulfur cycling in the phototrophic pink berry consortia of the Sippewissett Salt Marsh. Environmental Microbiology, 16, 3398-3415.

Wilkin, R. T., Arthur, M. A., \& Dean, W. E. (1997). History of water-column anoxia in the Black Sea indicated pyrite framboid size distributions. Earth and Planetary Science Letters, 148, 517-525.

Wilkin, R. T., Barnes, H. L., \& Brantley, S. L. (1996). The size distribution of framboidal pyrite in modern sediments: An indicator of redox conditions. Geochimica et Cosmochimica Acta, 60, 3897-3912. 
Williford, K. H., Ushikubo, T., Lepot, K., Kitajima, K., Hallmann, C., Spicuzza, M. J., ... Valley, J. W. (2016). Carbon and sulfur isotopic signatures of ancient life and environment at the microbial scale: Neoarchean shales and carbonates. Geobiology, 14(2), 105-128.

Williford, K. H., Van Kranendonk, M. J., Ushikubo, T., Kozdon, R., \& Valley, J. W. (2011). Constraining atmospheric oxygen and seawater sulfate concentrations during Paleoproterozoic glaciation: In situ sulfur threeisotope microanalysis of pyrite from the Turee Creek Group, Western Australia. Geochimica et Cosmochimica Acta, 75(19), 5686-5705.

Wing, B. A., \& Halevy, I. (2014). Intracellular metabolite levels shape sulfur isotope fractionation during microbial sulfate respiration. Proceedings of the National Academy of Science U S A, 111, 18116-18125.

Zerkle, A. L., Farquhar, J., Johnston, D. T., Cox, R. P., \& Canfield, D. E. (2009). Fractionation of multiple sulfur isotopes during phototrophic oxidation of sulfide and elemental sulfur by a green sulfur bacterium. Geochimica et Cosmochimica Acta, 73(2), 291-306.

Zhelezinskaia, I., Kaufman, A. J., Farquhar, J., \& Cliff, J. (2014). Large sulfur isotope fractionations associated with Neoarchean microbial sulfate reduction. Science, 346(6210), 742-744.

\section{SUPPORTING INFORMATION}

Additional Supporting Information may be found online in the supporting information tab for this article.

How to cite this article: Gomes ML, Fike DA, Bergmann KD, Jones $\mathrm{C}$, Knoll $\mathrm{AH}$. Environmental insights from highresolution (SIMS) sulfur isotope analyses of sulfides in Proterozoic microbialites with diverse mat textures.

Geobiology. 2017;00:1-18. https://doi.org/10.1111/gbi.12265 